\title{
Precipitation mechanism and mechanical properties of an ultra-high strength steel hardened by nanoscale $\mathrm{NiAl}$ and $\mathrm{Cu}$ particles
}

\author{
Z. B. Jiao' ${ }^{1}$ J. H. Luan ${ }^{1}$, M. K. Miller ${ }^{2}$, C. T. Liu, ${ }^{1, *}$ \\ ${ }^{1}$ Center for Advanced Structural Materials, Department of Mechanical and Biomedical \\ Engineering, College of Science and Engineering, City University of Hong Kong, Hong Kong, \\ China \\ ${ }^{2}$ Center for Nanophase Materials Sciences, Oak Ridge National Laboratory, Oak Ridge, TN \\ 37831, USA
}

\begin{abstract}
We report on the alloy design strategies, precipitation mechanism and mechanical properties of an ultra-high strength steel hardened by co-precipitation of nanoscale $\mathrm{NiAl}$ and $\mathrm{Cu}$ particles. The steel, developed through a computational-aided alloy design approach, exhibits a tensile strength of $\sim 1.9 \mathrm{GPa}$, an elongation of $\sim 10 \%$ and a reduction in area of $\sim 40 \%$. Atom probe tomography reveals an interesting type of co-precipitation mechanism of $\mathrm{NiAl}$ and $\mathrm{Cu}$ nanoparticles, in which the NiAl particles first come out of the supersaturated solid solution and the rejection of $\mathrm{Cu}$ solutes leads to the heterogeneous precipitation of $\mathrm{Cu}$ particles adjacent to the $\mathrm{NiAl}$ particles. The observed precipitation sequence of "supersaturated solid solution $\rightarrow \mathrm{NiAl} \rightarrow$ $\mathrm{NiAl}+\mathrm{Cu}$ " is substantially different from the one previously reported in $\mathrm{Cu}$-strengthened steels, which involves the process of "supersaturated solid solution $\rightarrow \mathrm{Cu} \rightarrow \mathrm{Cu}+\mathrm{NiAl}$ ". The modulation of the precipitation sequence is attributed not only to the relatively high $\mathrm{Ni} / \mathrm{Cu}$ and $\mathrm{Al} / \mathrm{Cu}$ ratios but also the synergistic combination of $\mathrm{Ni}, \mathrm{Al}, \mathrm{Mn}$ and $\mathrm{Cu}$ additions in the steel. $\mathrm{In}$

"Corresponding author: E-mail: chainliu@ @ityu.edu.hk, Tel: 852-34427213, Fax: 852-34420172


addition, APT also reveals the precipitation of a small amount of nanoscale $\mathrm{Fe}_{3}(\mathrm{Mo}, \mathrm{W})_{3} \mathrm{C}$ - and NbC-type carbides. The combination of the strengthening effects from the nanoscale NiAl particles, $\mathrm{Cu}$ particles and carbides contributes significantly to the overall ultra-high strength of the steel.

Keywords: $\mathrm{NiAl}$ and $\mathrm{Cu}$ co-precipitate; precipitation; mechanical property; structure-property relationship; atom probe tomography 


\section{Introduction}

Ultra-high strength steels are becoming increasingly important in aerospace, power generation, shipbuilding, and automotive industries. Basically, the strengthening of steels involves the controlled creation of internal obstacles to impede the motion of dislocations [1]. Uniform precipitation of nanoparticles has been recognized as one of the most effective methods to increase the tensile and/or creep strength of steels [2-7]. The degree of strengthening so obtained is highly dependent upon the type, number density, size and spatial distribution of the particles, and also the nature of the interaction of the dislocations with the particles [1]. Among the various types of potential nanoparticles to be considered for precipitation hardening in steels, $\mathrm{Cu}$ and $\mathrm{NiAl}$ nanoparticles constitute two classes of effective strengthening phases, allowing the development of low-carbon steels with a good combination of high strength, high ductility and good weldability [8-14].

Recently, the co-precipitation of nanoscale $\mathrm{Cu}$ and NiAl particles in high strength steels has attracted considerable attentions, which offer a promising way to effectively strengthen the steels without a significant reduction in ductility [15-18]. Previous work was focused mainly on the $\mathrm{Fe}-\mathrm{Cu}-\mathrm{Ni}-\mathrm{Al}$-based steels with relatively low $\mathrm{Ni} / \mathrm{Cu}$ and $\mathrm{Al} / \mathrm{Cu}$ ratios, in which $\mathrm{Cu}$ nanoparticles are the dominant strengthening phase and NiAl nanoparticles provide a supplement strengthening effect. Regarding to the precipitation mechanism, it is generally accepted that coherent body-centered cubic (bcc) $\mathrm{Cu}$ nanoparticles nucleate first from the supersaturated solid solution, and $\mathrm{Ni}$ and $\mathrm{Al}$ tend to segregate at the interface between the $\mathrm{Cu}$ nanoparticles and $\alpha-\mathrm{Fe}$ matrix[16,19-21]. The interfacial segregation of $\mathrm{Ni}$ and $\mathrm{Al}$ leads to the heterogeneous precipitation of $\mathrm{NiAl}$ adjacent to the $\mathrm{Cu}$ nanoparticles, thereby forming composite nanoparticles 
[22-26]. It is known that small variations in the $\mathrm{Ni}, \mathrm{Al}$ and $\mathrm{Cu}$ contents can lead to sensitive differences in the precipitation characteristics, including the composition, size and number density of the $\mathrm{Cu}$ and $\mathrm{NiAl}$ nanoparticles, thereby significantly influencing the degree of strengthening. Since NiAl, a highly stable B2-ordered intermetallic phase [27-29], is much harder than $\mathrm{Cu}$, it can provide more efficient strengthening effects in steels. Therefore, it is interesting to further tune the $\mathrm{Ni} / \mathrm{Cu}$ and $\mathrm{Al} / \mathrm{Cu}$ ratios to properly enhance the precipitation of $\mathrm{NiAl}$. To date, however, investigations on $\mathrm{Cu}$ - and $\mathrm{NiAl}$-strengthened steels with relatively high $\mathrm{Ni} / \mathrm{Cu}$ and $\mathrm{Al} / \mathrm{Cu}$ ratios are limited, and the corresponding precipitation mechanism remains elusive. Therefore, it is of both fundamental and technological importance to obtain detailed knowledge on the precipitation mechanism of the steels with relatively high $\mathrm{Ni} / \mathrm{Cu}$ and $\mathrm{Al} / \mathrm{Cu}$ ratios, so that the precipitation reaction may be controlled to achieve optimal properties.

The purposes of this work are twofold. First, to obtain a fundamental understanding of the co-precipitation mechanism of nanoscale $\mathrm{NiAl}$ and $\mathrm{Cu}$ particles in the steels with relative high $\mathrm{Ni} / \mathrm{Cu}$ and $\mathrm{Al} / \mathrm{Cu}$ ratios. Second, to develop new ultra-high strength steel by reasonably combining the strengthening effects of nanoscale $\mathrm{NiAl}$ and $\mathrm{Cu}$ particles as well as a small amount nanoscale carbides. In this work, a computational-aided alloy design approach was employed to guide the alloy design, and the precipitation nanostructural features and mechanical properties of the prototype steel were carefully characterized by experimental studies. Since the $\mathrm{Cu}$ and $\mathrm{NiAl}$ nanoparticles usually have a coherent relation to the magnetic Fe-based matrix, it is difficult to quantitatively characterize the morphology and composition of these nanoparticles, particularly in the early stages of precipitation, using conventional transmission electron microscope (TEM) because of a weak diffraction and phase contrast [16]. Atom probe tomography (APT) is an alternative high-resolution characterization method, which provides 
three-dimensional (3D) elemental mapping with nearly atomic resolution and gives information on the topology of interfaces and local chemical gradients [30-32]. In this work, the size, number density, composition, particle configuration and spatial distribution of the $\mathrm{NiAl}$ and $\mathrm{Cu}$ nanoparticles as a function of aging time were systematically characterized by APT. Particular attention was paid to the mechanistic understanding of the co-precipitation mechanism in the steel with relatively high $\mathrm{Ni} / \mathrm{Cu}$ and $\mathrm{Al} / \mathrm{Cu}$ ratios.

\section{Computational-aided alloy design}

Thermodynamic calculations offer an effective means by which the phase relationship in multi-component alloys can be readily predicted [33,34]. In this study, the Thermo-Calc 3.0.1 software with Fe database (TCFE7), a unique thermodynamic program for calculating phase constitutions and transformations in Fe-based multi-component alloys, is employed to provide guidelines for alloy design of the high-strength steel hardened by $\mathrm{NiAl}$ and $\mathrm{Cu}$ nanoparticles as well as a small amount of carbides. Each step of the alloy design procedure will be presented below.

First, the carbon content of the steel is set based on the consideration of both weldability and carbide hardening. Carbon is known as one of the most important alloying elements affecting the steel weldability, and high-carbon steels tend to suffer from solidification cracking in the welds [35]. Similar to the carbon level in the weldable, high-strength steels Navy HSLA80 and HSLA-100 [8], a low carbon content of 0.05 wt.\% is set for high weldability. Moreover, to prevent the formation of cementite and to ensure good ductility, strong carbide-forming elements, including $\mathrm{Nb}$, Mo and $\mathrm{W}$, are introduced into the steel. As suggested by commercial precipitation-hardening martensitic steels [36], a combination of $0.07 \mathrm{wt} . \% \mathrm{Nb}$ together with Mo 
and $\mathrm{W}$ is added to form nanoscale alloy carbides. In addition, boron has been found to improve the ductility of high-strength alloys by enhancing their grain-boundary cohesion and suppressing the intergranular fracture [37-39]. To achieve a good strength-ductility combination, the boron content is set to be $0.01 \mathrm{wt} . \%$ in the steel.

Second, $\mathrm{Cu}$ precipitation characteristics are strongly dependent on the $\mathrm{Cu}$ supersaturation and aging condition used. A solutionizing treatment at $900{ }^{\circ} \mathrm{C}$ and an aging treatment at $550{ }^{\circ} \mathrm{C}$ are initially chosen based on the previous studies for optimizing the particle and grain sizes in $\mathrm{Cu}$ - and NiAl-strengthened steels [26,40]. The fraction of the $\mathrm{Cu}$ phase as a function of $\mathrm{Cu}$ content and heat-treatment temperature is calculated by Thermo-Calc, as shown in Fig. 1a. At $550{ }^{\circ} \mathrm{C}$, less than $0.2 \mathrm{wt} . \% \mathrm{Cu}$ would be completely dissolved in the $\alpha$-Fe solid solution, while at $900{ }^{\circ} \mathrm{C}$, the $\mathrm{Cu}$ phase starts to precipitate out when the $\mathrm{Cu}$ content is greater than 3.5 wt.\%. Therefore, the $\mathrm{Cu}$ level should be within the range of 0.2-3.5 wt.\%. Previous studies also suggest that the $\mathrm{Cu}$ content should be at least $1.0 \mathrm{wt} . \%$ for significant strengthening [8-10,22-26]. On the other hand, $\mathrm{Cu}$ has a low melting point compared to the $\alpha$-Fe matrix, and excessive $\mathrm{Cu}$ additions tend to cause a hot cracking phenomenon known as "hot shortness" [41]. Based on these considerations, the $\mathrm{Cu}$ content in the steel is set to be $1.5 \mathrm{wt} . \%$.

Finally, the content of $\mathrm{Ni}, \mathrm{Al}$ and $\mathrm{Mn}$ are optimized to promote the formation of $\mathrm{NiAl}-$ type nanoparticles while minimizing the formation of undesired phases including retained austenite and $\delta$-ferrite. It is noted that $\mathrm{Ni}$, an austenite stabilizer, encourages the formation of retained austenite, while too much $\mathrm{Al}$ would lead to the retention of $\delta$-ferrite. It was reported that $15 \%$ retained austenite in precipitation hardened steels would not significantly degrade the strength [42], while even a small fraction of $\delta$-ferrite seriously worsened the toughness [43]. Thus, an upper limit of $15 \%$ for retained austenite and zero tolerance for $\delta$-ferrite are set in the 
steel. To predict the allowable $\mathrm{Ni}$ and $\mathrm{Al}$ contents, the fraction of retained austenite and $\delta$-ferrite as a function of $\mathrm{Ni}$ and $\mathrm{Al}$ contents are calculated by Thermo-Calc. The isothermal sections of the Fe- $x \mathrm{Ni}-y \mathrm{Al}-1.5 \mathrm{Cu}-1.5 \mathrm{Mo}-1.5 \mathrm{~W}-0.07 \mathrm{Nb}-0.05 \mathrm{C}-0.01 \mathrm{~B}$ system at a solutionizing temperature of $900{ }^{\circ} \mathrm{C}$ and an aging temperature of $550{ }^{\circ} \mathrm{C}$ are illustrated in Fig. $1 \mathrm{~b}$ and c, respectively. The fraction of $\delta$-ferrite at $900{ }^{\circ} \mathrm{C}$ increases with increasing $\mathrm{Al}$ contents and decreasing Ni contents, whereas that of retained austenite at $550{ }^{\circ} \mathrm{C}$ behaves in the opposite way. The composition range fulfilling the requirements for both retained austenite and $\delta$-ferrite is shown in Fig. 1d. The composition with $8 \mathrm{wt} . \% \mathrm{Ni}$ and $2 \mathrm{wt} . \% \mathrm{Al}$ (indicated by the black dot) is close to the maximum alloying level. Considering the stoichiometry of the NiAl intermetallic compound, $5 \mathrm{wt} \% \mathrm{Ni}$ is enough for fixing $2 \mathrm{wt} . \% \mathrm{Al}$. The remaining Ni can be substituted by $\sim 3 \mathrm{wt} . \% \mathrm{Mn}$, since $\mathrm{Mn}$ has a similar effect on retarding the formation of $\delta$-ferrite as Ni. In addition, Mn plays an important

role in enhancing the nanoscale precipitation of NiAl by partially substituting for $\mathrm{Al}$ [44]. More importantly, the substitution of $\mathrm{Mn}$ for Ni significantly lowers the material cost, which is in line with the design of cost-effective steels. Based on all above design guidance, the final optimal composition is derived as Fe-5Ni-2Al-3Mn-1.5Cu-1.5Mo-1.5W-0.07Nb-0.05C-0.01B (wt.\%).

\section{Experimental}

Alloy ingots were prepared by arc-melting a mixture of the constituent elements with purity better than 99.9 wt.\% in a Ti-gettered high-purity argon atmosphere. Repeated melting was carried out at least five times to ensure the chemical homogeneity. The melted alloys were then drop-cast into a copper mold with dimensions of $15 \times 30 \times 100 \mathrm{~mm}$. The resulting plates were successfully cold rolled without difficulties by multiple passes with a total reduction of $\sim 66 \%$ 
and solution-treated for $30 \mathrm{~min}$ at $900{ }^{\circ} \mathrm{C}$, followed by water quenching, and then aged isothermally at 400 to $550{ }^{\circ} \mathrm{C}$ for various periods of time up to $128 \mathrm{~h}$.

Sections of the heat-treated samples perpendicular to the rolling direction were polished to a final surface finish of $0.05 \mu \mathrm{m}$ using standard mechanical polishing procedures. Hardness measurements were conducted on polished surface of the samples using a Vickers hardness tester with a load of $2 \mathrm{~N}$ for $15 \mathrm{~s}$, and for each specimen, at least 8 indents were measured to obtain an average value.

Tensile samples with a cross-section of $3.2 \times 1 \mathrm{~mm}$ and a gauge length of $12.5 \mathrm{~mm}$ were cut by electro-discharge machining, and ground careful on each side with SiC paper through 4000 grit. Tensile tests along the rolling direction of the samples were conducted on an MTS tensile testing machine at a strain rate of $10^{-3} \mathrm{~s}^{-1}$. Fracture surfaces were examined by scanning electron microscopy (SEM).

Thin TEM foils were prepared with care for a large electron transparent area and minimum magnetic influence. 3-mm-diameter discs were thinned to electron transparent by a twin-jet electrochemical polisher at $35 \mathrm{~V}$ in a 5 vol. $\% \mathrm{HClO}_{4}$ methanol electrolyte at a low temperature. The thin foils were then gently ion milled to remove surface contamination. TEM characterization was conducted using a JEOL 2100F microscope operated at $200 \mathrm{kV}$.

The needle-shaped specimens required for APT were fabricated by a combination of standard electropolishing methods followed by annular milling in a FEI Nova 200 focused ion beam/scanning electron microscope (FIB/SEM) [30]. The APT characterizations were performed in a CAMECA Instruments LEAP 4000X HR local electrode atom probe. The specimens were analyzed in voltage mode, with a specimen temperature of $50 \mathrm{~K}$, a pulse repetition rate of 200 $\mathrm{kHz}$, a pulse fraction of 0.2 , and an ion collection rate of between $0.5 \%$ and $1 \%$ ions per field 
evaporation pulse. Imago Visualization and Analysis Software (IVAS) version 3.6.6 was used for $3 \mathrm{D}$ reconstructions, composition analysis and the creation of isoconcentration surfaces.

\section{Results}

\subsection{Mechanical properties}

Hardness measurements were conducted to evaluate the age hardening response of the steel. The Vickers hardness of the specimens aged for up to $128 \mathrm{~h}$ at 400 to $550{ }^{\circ} \mathrm{C}$ is shown in Fig. 2. The steel shows a hardness of $\sim 440 \mathrm{HV}$ in the as-quenched condition. At aging temperatures of 400 and $450{ }^{\circ} \mathrm{C}$, no hardness peaks appear within the $128 \mathrm{~h}$ aging period, indicating that the age hardening kinetics is very slow at these temperatures. Upon aging at $500{ }^{\circ} \mathrm{C}$, the hardness increases gradually to $\sim 615 \mathrm{HV}$ after aging for $8 \mathrm{~h}$, and prolonged aging leads to the decrease of the hardness due to an over-aging effect. During aging at $550{ }^{\circ} \mathrm{C}$, the steel shows a similar trend in hardness as that at $500{ }^{\circ} \mathrm{C}$ but at a relative fast rate of age hardening, reaching the peak hardness of $\sim 620 \mathrm{HV}$ at $2 \mathrm{~h}$, resulting in a pronounced increase in hardness $(\sim 180 \mathrm{HV})$ as compared with the as-quenched sample. The above results indicate that the aging treatment at $550{ }^{\circ} \mathrm{C}$ provides an appropriate condition for obtaining a substantial age hardening response within a reasonable period of time.

Room-temperature tensile tests were performed to further investigate the mechanical behavior of the steel in the peak hardening condition (aging at $550{ }^{\circ} \mathrm{C}$ for $2 \mathrm{~h}$ ). The engineering stress-strain curve of the steel is shown in Fig. 3, and the corresponding fracture surfaces are shown in the insets. The steel exhibits an ultimate tensile strength of $\sim 1.9 \mathrm{GPa}$, an elongation-tofailure of $\sim 10 \%$ and a reduction in area of $\sim 40 \%$, indicating a good combination of ultra-high strength and good ductility. In addition, obvious necking and large reductions in area are clearly 
observed from the fractured samples. The fracture surface shows a micro-void coalescence fracture mode with a lot of fine dimples, indicating a characteristic mode of a ductile fracture.

It is expected that the mechanical properties can be further optimized by optimizing the alloy composition and heat-treatment parameters, which merits a systematical investigation in the future. In the subsequent sections, we will focus our efforts on the mechanistic understanding of the nanoscale precipitation and properties of the ultra-high strength steel.

\subsection{APT and TEM characterization}

\subsubsection{Characterization of nanoscale carbides}

The microstructure of nanoscale carbides in the specimen aged for $2 \mathrm{~h}$ at $550{ }^{\circ} \mathrm{C}$ were characterized by TEM. Two categories of spheroidal nanoscale carbides are observed, as shown in Fig. 4a, one category with an average diameter of $\sim 40 \mathrm{~nm}$ and the other category of $\sim 10 \mathrm{~nm}$. The energy dispersive spectroscopy (EDS) spectrums of the two categories of nanoscale carbides are presented in Fig. 4b. The EDS analysis reveals that the coarser carbides are enriched in Mo and $\mathrm{W}$, whereas the finer ones are enriched in $\mathrm{Nb}$. High-resolution TEM image of a representative $\mathrm{Mo} / \mathrm{W}$-enriched carbide and its corresponding fast Fourier transformation (FFT) pattern are presented in the insets in Fig. 4a. The FFT pattern together with the EDS spectrum indicates that the coarser carbides are of $\mathrm{Fe}_{3} \mathrm{Mo}_{3} \mathrm{C}$-type.

Moreover, the Mo/W-enriched and $\mathrm{Nb}$-enriched carbides are also detected by APT. One advantage of APT over other nanoanalytical techniques is the quantitative detection of all elements with a super-high sensitivity, including the light-element carbon for which concentration is not readily quantified by TEM/EDS analysis, in particular when the nanoscale

features of interest are smaller than the TEM foil thickness [30-32]. The APT compositions of 
the two types of nano-carbides, as estimated from the deconvolution of the peaks in the mass spectra of ions collected from the interior of the particles, are given in Table 1. The atomic ratio of Fe:(Mo+W):C in the coarser carbides is approximately 3:3:1, which is in accordance to that of $\mathrm{Fe}_{3}(\mathrm{Mo}, \mathrm{W})_{3} \mathrm{C}$-type carbides and in agreement with the TEM results. The atomic ratio of $(\mathrm{Nb}+\mathrm{Mo}+\mathrm{W}): \mathrm{C}$ in the finer carbides is close to $\sim 1$, suggesting these finer carbides are of $\mathrm{NbC}-$ type with certain amounts of Mo and W substitutional for partial $\mathrm{Nb}$.

\subsubsection{Nanoscale co-precipitation of NiAl and $\mathrm{Cu}$ particles}

We now characterize the detailed precipitation evolution of the nanoscale $\mathrm{NiAl}$ and $\mathrm{Cu}$ particles, the primary strengthening phases in the steel. The $25 \%(\mathrm{Ni}+\mathrm{Al})$ concentration and $5 \%$ $\mathrm{Cu}$ concentration isosurfaces are used to visualize the $\mathrm{NiAl}$ and $\mathrm{Cu}$ nanoparticles, respectively. The nanostructures of the two types of particles in the specimens after aging for $0.5,2,8$ and 128 h at $550{ }^{\circ} \mathrm{C}$ are shown in Fig. 5a, b, c and d, respectively. High number densities of spheroidal $\mathrm{NiAl}$ and $\mathrm{Cu}$ nanoparticles are detected readily in the $0.5-8 \mathrm{~h}$ aged specimens, and both types of particles tend to coarsen with aging time. In the $128 \mathrm{~h}$ condition, a $\mathrm{Cu}$ particle in close contact with a NiAl particle is observed, but both particles are too coarse for quantitative analysis of sizes and number densities. Nevertheless, the compositions in this long-term aged condition can be analyzed, which is helpful in gaining an insight into the compositional evolution of the nanoparticles.

The average radius and number density of the $\mathrm{NiAl}$ and $\mathrm{Cu}$ nanoparticles as a function of aging time are shown in Fig. 6a and b, respectively. Upon isothermal aging at $550{ }^{\circ} \mathrm{C}$, the average radius of the $\mathrm{NiAl}$ particles increases continuously from $\sim 1.1 \pm 0.4 \mathrm{~nm}$ at $0.5 \mathrm{~h}$ to $\sim 1.7 \pm$ $0.56 \mathrm{~nm}$ at $2 \mathrm{~h}$ and further to $\sim 2.8 \pm 1.0 \mathrm{~nm}$ at $8 \mathrm{~h}$, while that of the $\mathrm{Cu}$ particles increases 
slightly from $\sim 1.1 \pm 0.4 \mathrm{~nm}$ at $0.5 \mathrm{~h}$ to $\sim 1.4 \pm 0.5 \mathrm{~nm}$ at $2 \mathrm{~h}$ and further to $\sim 1.9 \pm 0.7 \mathrm{~nm}$ at $8 \mathrm{~h}$. Meanwhile, the number density of the NiAl nanoparticles decreases monotonically from $\sim 3.9 \times$ $10^{24} \mathrm{~m}^{-3}$ at $0.5 \mathrm{~h}$ to $\sim 2.8 \times 10^{24} \mathrm{~m}^{-3}$ at $2 \mathrm{~h}$ and further to $\sim 5.0 \times 10^{23} \mathrm{~m}^{-3}$ at $8 \mathrm{~h}$. In comparison, the variation of the $\mathrm{Cu}$ nanoparticles in number density is rather complex with aging time, which increases from $\sim 2.5 \times 10^{23}$ to $\sim 5.2 \times 10^{23} \mathrm{~m}^{-3}$ as the aging time increases from $0.5 \mathrm{~h}$ to $2 \mathrm{~h}$ and then decreases to $\sim 2.2 \times 10^{23} \mathrm{~m}^{-3}$ when the aging time further increases to $8 \mathrm{~h}$. Note that the number density of the $\mathrm{NiAl}$ nanoparticles is more than an order of magnitude higher than that of the $\mathrm{Cu}$ nanoparticles in the $0.5 \mathrm{~h}$ condition, and the difference between the two types of nanoparticles in number density becomes smaller with aging time.

More interestingly, the relative number and location of the $\mathrm{NiAl}$ and $\mathrm{Cu}$ nanoparticles as a function of aging time can be determined by APT, and the statistical analysis of the particle configurations is illustrated in Fig. 7 . In the $0.5 \mathrm{~h}$ condition, the $25 \mathrm{~nm} \times 25 \mathrm{~nm} \times 50 \mathrm{~nm}$ volume contains 202 spheroidal NiAl particles and 13 spheroidal $\mathrm{Cu}$ particles. The majority of the NiAl particles are isolated particles with no $\mathrm{Cu}$ particles associated with them, and only $\sim 6 \%$ of the $\mathrm{NiAl}$ particles are $\mathrm{NiAl} / \mathrm{Cu}$ co-precipitates, in which the $\mathrm{Cu}$ particles are located on the outside surface of the $\mathrm{NiAl}$ particles. It is worthwhile to point that no isolated $\mathrm{Cu}$ particles are observed in this condition. In the $2 \mathrm{~h}$ condition, the $40 \mathrm{~nm} \times 40 \mathrm{~nm} \times 50 \mathrm{~nm}$ volume contains 141 spheroidal NiAl particles and 32 spheroidal $\mathrm{Cu}$ particles. Statistical analysis indicates that $23 \%$ of the $\mathrm{NiAl}$ particles have $\mathrm{Cu}$ particles associate with them and the remainders are isolated $\mathrm{NiAl}$ particles. In the $8 \mathrm{~h}$ condition, the $45 \mathrm{~nm} \times 45 \mathrm{~nm} \times 50 \mathrm{~nm}$ volume contains 58 spheroidal NiAl particles and 18 spheroidal $\mathrm{Cu}$ particles, in which the fraction of the $\mathrm{NiAl} / \mathrm{Cu}$ co-precipitates further increases to $\sim 69 \%$, which is accompanied by the fraction of the isolated NiAl particles further decreasing to $\sim 31 \%$. 
1-nm-thick atom maps through the centers of the two types of particle configurations are shown in Fig. 8 as a function of aging time, in which the relative positions and extents of the Al (cyan), $\mathrm{Ni}(\mathrm{red})$ and $\mathrm{Cu}$ (green) atoms are indicated. The first type of configuration (the left of Fig. 8a-c) is the precipitation of isolated NiAl particles, in which $\mathrm{Ni}$ and $\mathrm{Al}$ together with a considerable amount of $\mathrm{Cu}$ are enriched in the particles. However, the $\mathrm{Cu}$ atoms are nearuniformly distributed in the NiAl particles with no significant clustering. The second type of configuration (the right of Fig. 8a-c) is the precipitation of $\mathrm{NiAl} / \mathrm{Cu}$ co-precipitates, in which the $\mathrm{Cu}$ particles are located on the outside surface of the NiAl particles. In the $0.5 \mathrm{~h}$ condition, the $\mathrm{Cu}$ particles overlaps largely with the $\mathrm{NiAl}$ particles and contains significant amounts of $\mathrm{Ni}$ and $\mathrm{Al}$, indicating that the composition of the $\mathrm{Cu}$ particles is far from equilibrium. With the increasing aging time, the degree of overlapping between the $\mathrm{NiAl}$ and $\mathrm{Cu}$ particles becomes smaller.

The estimated compositions of the $\mathrm{NiAl}$ and $\mathrm{Cu}$ nanoparticles in different aging conditions are summarized in Fig. 9a and b, respectively. The compositions after aging for 0.5, 2 and $8 \mathrm{~h}$ were estimated from the central region of the particles based on information from the proximity histograms, whereas that in the $128 \mathrm{~h}$ condition were derived from the mass peak deconvolution method of the interior of the $\mathrm{NiAl}$ and $\mathrm{Cu}$ nanoparticles. In the $0.5 \mathrm{~h}$ condition, the NiAl particles contain $32.13 \pm 0.57$ at. $\% \mathrm{Ni}, 25.38 \pm 0.53$ at.\% $\mathrm{Al}, 9.34 \pm 0.35$ at.\% $\mathrm{Mn}$, $11.80 \pm 0.39$ at. $\% \mathrm{Cu}$ and $21.34 \pm 0.50$ at.\% Fe. The concentrations of $\mathrm{Ni}, \mathrm{Al}$ and $\mathrm{Mn}$ increase continuously with aging time, reaching values of $49.40 \pm 0.26$ at. $\%, 31.12 \pm 0.23$ at.\% and 11.67 \pm 0.16 at. $\%$, respectively, after aging for $128 \mathrm{~h}$, whereas that of $\mathrm{Cu}$ and $\mathrm{Fe}$ decrease significantly with aging time, achieving values of $3.53 \pm 0.11$ at. $\%$ and $4.28 \pm 0.12$ at. $\%$, respectively, after aging for $128 \mathrm{~h}$. In the long-term aged condition $(128 \mathrm{~h})$, the ratio of $\mathrm{Ni}:(\mathrm{Al}+\mathrm{Cu}+\mathrm{Mn}+\mathrm{Fe})$ is 
close to $\sim 50: 50$, suggesting the $\mathrm{NiAl}$ particles are of NiAl-type with certain amounts of $\mathrm{Cu}$ and Mn substitutional for partial Al. The compositions of the $\mathrm{Cu}$ nanoparticles are illustrated in Fig. 9b. At $0.5 \mathrm{~h}$, the $\mathrm{Cu}$ particles are enriched in $\mathrm{Cu}(29.63 \pm 2.26$ at.\%) but also contains significant amounts of $\mathrm{Fe}(28.79 \pm 1.15$ at.\%), $\mathrm{Ni}(23.37 \pm 1.08$ at.\%), $\mathrm{Al}(11.62 \pm 0.81$ at.\%) and $\mathrm{Mn}(6.58$ \pm 0.53 at.\%). As the aging time increases from 0.5 to $2 \mathrm{~h}$, the $\mathrm{Cu}$ particles show only a slight change in composition. Upon further aging, the $\mathrm{Cu}$ concentration in the $\mathrm{Cu}$ particles increases to $54.67 \pm 0.94$ at. $\%$ at $8 \mathrm{~h}$ and further to $74.96 \pm 0.30$ at.\% at $128 \mathrm{~h}$. Meanwhile, the concentrations of $\mathrm{Ni}, \mathrm{Al}$ and $\mathrm{Fe}$ decrease continuously with aging time, reaching values of $5.52 \pm 0.18$ at.\%, $5.76 \pm 0.17$ at. $\%$ and $5.40 \pm 0.17$ at. $\%$, respectively, after aging for $128 \mathrm{~h}$. In this condition, the $\mathrm{Cu}$ concentration $(74.96 \pm 0.30$ at. $\%)$ is much lower than that reported after a long-term aging (97.6 at.\%) in a Fe-Cu-based steel [45], indicates that the $\mathrm{Cu}$ particles in the $128 \mathrm{~h}$ condition is still far from the equilibrium phase.

\section{Discussion}

The results above indicate that upon aging, the nanoscale $\mathrm{NiAl}$ and $\mathrm{Cu}$ particles undergo a rather complex evolution, involving the changes in size, number density, configuration and composition. In the following sections, the precipitation mechanism of the studied ultra-high strength steel will be discussed and also compared with previous results observed in other $\mathrm{Cu}$ and NiAl-strengthened steels with relatively low $\mathrm{Ni} / \mathrm{Cu}$ and $\mathrm{Al} / \mathrm{Cu}$ ratios. This comparison is expected to reveal the detailed precipitation mechanism in the steels relatively high $\mathrm{Ni} / \mathrm{Cu}$ and $\mathrm{Al} / \mathrm{Cu}$ ratios.

We first analyze the precipitation sequence of the nanoscale $\mathrm{NiAl}$ and $\mathrm{Cu}$ particles in the steel during isothermal aging at $550{ }^{\circ} \mathrm{C}$. At the early stage of precipitation (the $0.5 \mathrm{~h}$ condition), 
the majority of the $\mathrm{NiAl}$ nanoparticles ( 94\% in fraction) are isolated particles with no $\mathrm{Cu}$ particles associated with them, and the number density of the NiAl nanoparticles $\left(\sim 3.9 \times 10^{24} \mathrm{~m}^{-3}\right)$ is more than an order of magnitude larger than that of the $\mathrm{Cu}$ nanoparticles $\left(\sim 2.5 \times 10^{23} \mathrm{~m}^{-3}\right)$, these indicating that the NiAl nanoparticles essentially first come out of the supersaturated solid solution. As the aging time increases, the relative number of the $\mathrm{Cu}$ particles located on the $\mathrm{NiAl}$ particle surface increases gradually from $6 \%$ at $0.5 \mathrm{~h}$ to $23 \%$ at $2 \mathrm{~h}$ and further to $69 \%$ at $8 \mathrm{~h}$, suggesting that the $\mathrm{Cu}$ nanoparticles form after the $\mathrm{NiAl}$ nanoparticles in the aging sequence. In addition, the number density of the $\mathrm{NiAl}$ nanoparticles decreases monotonically with aging time, from $\sim 3.9 \times 10^{24} \mathrm{~m}^{-3}$ at $0.5 \mathrm{~h}$ to $\sim 5.0 \times 10^{23} \mathrm{~m}^{-3}$ at $8 \mathrm{~h}$, while that of $\mathrm{Cu}$ nanoparticles increases from $\sim 2.5 \times 10^{23}$ to $\sim 5.2 \times 10^{23} \mathrm{~m}^{-3}$ as the aging time increases from 0.5 to $2 \mathrm{~h}$ but then drops to $\sim 2.2 \times 10^{23} \mathrm{~m}^{-3}$ upon further aging to $8 \mathrm{~h}$, which further confirms that the $\mathrm{Cu}$ nanoparticles form at a later stage of precipitation, as compared with the NiAl nanoparticles.

It is interesting to note that although the $\mathrm{Cu}$ nanoparticles form after the $\mathrm{NiAl}$ nanoparticles in the aging sequence, a significant amount of $\mathrm{Cu}$ is enriched in the $\mathrm{NiAl}$ nanoparticles at the early stage of precipitation (see Figs. 8 and 9). Since $\mathrm{Cu}$ has a marginal solubility in the $\alpha$-Fe matrix, it can easily be incorporated in the NiAl precipitation process. When the NiAl phase is Ni-rich, $\mathrm{Cu}$ has been found to be energetically favorable in occupying the $\mathrm{Al}$ sublattice [46]. Because the atomic radius of $\mathrm{Cu}(1.28 \AA)$ is significantly smaller than that of $\mathrm{Al}(1.43 \AA)$, the substitution of $\mathrm{Cu}$ for $\mathrm{Al}$ would significantly reduce the lattice misfit strain between the NiAl particles and the $\alpha-\mathrm{Fe}(1.24 \AA)$ matrix [47]. As a result, the critical energy for the nucleation of the $\mathrm{NiAl}$ particles can be reduced, thereby promoting the precipitation of $\mathrm{Ni}(\mathrm{Al}, \mathrm{Cu})$. Therefore, the $\mathrm{Cu}$ solutes, enriched in the NiAl-type nanoparticles, play an important role in enhancing the precipitation of $\mathrm{NiAl}$, which is similar as the role of $\mathrm{Mn}$ in the $\mathrm{NiAl}$ 
precipitation [44]. Furthermore, the APT results also suggest that the majority of the $\mathrm{Cu}$ nanoparticles are formed by the mechanism involving the rejection of $\mathrm{Cu}$ solute atoms from the $\mathrm{Ni}(\mathrm{Al}, \mathrm{Cu})$ particles. This mechanism is supported based on the facts that the $\mathrm{Cu}$ nanoparticles are always located on the surface of the $\mathrm{NiAl}$ nanoparticles, and that the degree of overlapping between the $\mathrm{Cu}$ and $\mathrm{NiAl}$ nanoparticles becomes smaller with aging time. The rejection of $\mathrm{Cu}$ solutes from the NiAl nanoparticles can be explained by the positive heat of mixing of the $\mathrm{Cu}-\mathrm{Ni}$ pair $(+4 \mathrm{~J} / \mathrm{m})$ as the driving force for the phase separation [48], accompanying the evolution of the $\mathrm{NiAl}$ and $\mathrm{Cu}$ particles towards the equilibrium state.

Based on the above discussion on the formation and evolution of the $\mathrm{NiAl}$ and $\mathrm{Cu}$ nanoparticles, the precipitation mechanism of the studied steel can be summarized as follows and schematically illustrated in Fig. 10. At the initial stage of precipitation, the NiAl nanoparticles, enriched in $\mathrm{Ni}$ and $\mathrm{Al}$ together with considerable amounts of $\mathrm{Cu}$, first come out of the supersaturated solid solution; as the precipitation reaction continues, the first formation of the $\mathrm{NiAl}$ particles leads to the rejection of $\mathrm{Cu}$ solutes outwards the $\mathrm{NiAl}$ particles, resulting in the heterogeneous precipitation of $\mathrm{Cu}$ nanoparticles adjacent to the NiAl nanoparticles. Put succinctly, the precipitation sequence in the studied steel can be expressed as

$$
\text { "supersaturated solid solution } \rightarrow \mathrm{NiAl} \rightarrow \mathrm{NiAl}+\mathrm{Cu} \text { ", }
$$

which is significantly different from the one previously reported in $\mathrm{Cu}$-strengthened steels, involving the process [15-26] of

$$
\text { "supersaturated solid solution } \rightarrow \mathrm{Cu} \rightarrow \mathrm{Cu}+\mathrm{NiAl} \text { ". }
$$

In the previously reported $\mathrm{Fe}-\mathrm{Cu}-\mathrm{Ni}$-Al-based steels with low $\mathrm{Ni} / \mathrm{Cu}$ and $\mathrm{Al} / \mathrm{Cu}$ ratios, the $\mathrm{Cu}$ particles, rather than the NiAl particles, nucleate first from the supersaturated solid solution, and both $\mathrm{Ni}$ and $\mathrm{Al}$ tend to segregate at the interface between the $\mathrm{Cu}$ particles and the matrix. At a 
later stage of precipitation, the interfacial segregation of $\mathrm{Ni}$ and $\mathrm{Al}$ leads to the heterogeneous nucleation of $\mathrm{NiAl}$ at the $\mathrm{Cu}$ particle/matrix interface.

From the thermodynamic point of view, the precipitation sequence of different types of particles is determined by the competition of the nucleation driving force of the competing phases [36], dependent strongly upon not only the concentration of the particle forming elements but also other alloying elements that might affect the nucleation barrier. The modulating of the precipitation sequence in the steel can be explained from three aspects. First, the studied steel contains sufficiently enough $\mathrm{Ni}$ and $\mathrm{Al}$ concentrations beyond the miscibility gap for disordered bcc-ferrite and $\mathrm{B} 2$-ordered $\mathrm{NiAl}$, which makes the independent nucleation of $\mathrm{NiAl}$ in the $\alpha$-Fe matrix possible. Previous studies indicated that for the homogeneous precipitation of $\mathrm{NiAl}$ in $\mathrm{Cu}-$ free steels, the $\mathrm{Ni}$ and $\mathrm{Al}$ contents should be at least 2.5 and $1 \mathrm{wt} \%$, respectively [40]. In this study, the concentrations of $\mathrm{Ni}$ and $\mathrm{Al}$ in the steel (5 and $2 \mathrm{wt} . \%$, respectively) far exceed the miscibility limit of the two elements, showing a high supersaturation for the precipitation of NiAl. Second, this steel has relatively high ratios of $\mathrm{Ni} / \mathrm{Cu}$ and $\mathrm{Al} / \mathrm{Cu}$, as compared with the previous studied $\mathrm{Cu}$-strengthened steels. As listed in Table 2, the $\mathrm{Ni} / \mathrm{Cu}$ and $\mathrm{Al} / \mathrm{Cu}$ ratios in previous studied alloys are usually less than 2 and 0.5 , respectively, while that in the present steel are $\sim 3.33$ and $\sim 1.33$, respectively. It is expected that the relatively high $\mathrm{Ni} / \mathrm{Cu}$ and $\mathrm{Al} / \mathrm{Cu}$ ratios would yield a higher chemical driving force for the precipitation of $\mathrm{NiAl}$ relative to that of the $\mathrm{Cu}$ particles. Third, APT reveals that $\mathrm{Cu}$ and $\mathrm{Mn}$ tend to partition into the NiAl nanoparticles at the early stages of precipitation by substituting for partial $\mathrm{Al}$, which can significantly reduce the strain energy for the formation of NiAl nanoparticles, thereby substantially enhancing the precipitation of NiAl. In addition, as compared with other NiAl-strengthened maraging steels which usually contain high $\mathrm{Ni}$ and $\mathrm{Al}$ contents in order to form adequate $\mathrm{NiAl}$ particles, the 
additions of $\mathrm{Cu}$ and $\mathrm{Mn}$ in the studied steel help to reduce the steel cost, because $\mathrm{Cu}$ and $\mathrm{Mn}$ are much cheaper than Ni. Therefore, the synergistic combination of $\mathrm{Ni}, \mathrm{Al}, \mathrm{Cu}$ and $\mathrm{Mn}$ additions play an important role in modulating the precipitation sequence from "supersaturated solid solution $\rightarrow \mathrm{Cu} \rightarrow \mathrm{Cu}+\mathrm{NiAl}$ " to "supersaturated solid solution $\rightarrow \mathrm{NiAl} \rightarrow \mathrm{NiAl}+\mathrm{Cu}$ ", leading to the formation of an extremely high number density of NiAl nanoparticles $\left(\sim 3.9 \times 10^{24}\right.$ and $\sim 2.8 \times 10^{24} \mathrm{~m}^{-3}$ at 0.5 and $2 \mathrm{~h}$, respectively) as the dominant strengthening phase in the steel.

It is well known that NiAl intermetallic nanoparticles constitute one of the most effective strengthening phases (much more effective than $\mathrm{Cu}$ nanoparticles), because high-energy antiphase boundaries (APB) must be created by moving single dislocations [49], thereby resulting in a high strengthening efficiency. In this study, the NiAl nanoparticles have a large number density of above $2 \times 10^{24} \mathrm{~m}^{-3}$ and fine particle size of $1-5 \mathrm{~nm}$, thereby providing a significant contribution to the ultra-high strength of the steel. In addition, the steel also contains a high number density of $\mathrm{Cu}$ nanoparticles $\left(2.5 \times 10^{23}\right.$ and $\sim 5.2 \times 10^{23} \mathrm{~m}^{-3}$ at 0.5 and $2 \mathrm{~h}$, respectively) and a small amount of nanoscale carbides, which provide a supplement strengthening effect. The combination of the strengthening effects from the $\mathrm{NiAl}$ and $\mathrm{Cu}$ nanoparticles and nano-carbides can greatly contribute to the overall ultra-high strength of the steel. Therefore, by optimizing alloying additions of $\mathrm{Ni}, \mathrm{Al}, \mathrm{Cu}$ and $\mathrm{Mn}$, controlling the precipitation mechanism, and engineering the precipitation nanostructural features, the ultra-high strength steel has been developed with a reduced $\mathrm{Ni}$ content, thereby being relatively cost-effective as compared with maraging steels [36]. It is anticipated that this steel with a good combination of ultra-high strength and good ductility has a great potential for structural applications. In addition, the nanoengineering approach, in principle, can be applied to explore other alloy systems for improved 
performance, which provides an effective route for strengthening materials without significantly scarifying other important properties.

\section{Summary}

This study presents the mechanistic understanding of the development of an ultra-high strength steel hardened by a group of nanoparticles through a computational-aided alloy design approach, and the precipitation nanostructural features and mechanical properties were carefully characterized by experimental studies mainly using APT, the state-of-the-art nanoanalytical tool. The following conclusions can be drawn from the current study:

1. The ultra-high strength steel was developed in the Fe-Ni-Al-Mn-Cu-Mo-W-Nb-C-B multi-component alloy system through a computational-aided alloy design approach. The steel exhibits a remarkable age hardening response during isothermal aging at 450$550{ }^{\circ} \mathrm{C}$. In the peak hardening condition, the steel shows an ultimate tensile strength of $\sim 1.9 \mathrm{GPa}$, an elongation of $\sim 10 \%$ and a reduction in area of $\sim 40 \%$, indicating a good combination of ultra-high strength and good ductility.

2. APT reveals the formation of high number densities of $1-5 \mathrm{~nm} \mathrm{NiAl}$ and $\mathrm{Cu}$ particles in the aged specimens. In the $0.5 \mathrm{~h}$ condition, the majority of the NiAl nanoparticles ( $94 \%)$ are isolated particles with no $\mathrm{Cu}$ particles associated with them, and the number density of the NiAl nanoparticles is more than an order of magnitude higher than that of the $\mathrm{Cu}$ nanoparticles. The relative number of the $\mathrm{Cu}$ nanoparticles located on the NiAl particle surface increases gradually from $6 \%$ at $0.5 \mathrm{~h}$ to $23 \%$ at $2 \mathrm{~h}$ and further to $69 \%$ at $8 \mathrm{~h}$. In addition, a small amount of nanoscale $\mathrm{Fe}_{3}(\mathrm{Mo}, \mathrm{W})_{3} \mathrm{C}$ - and $\mathrm{NbC}$-type carbides are also detected by TEM and APT. 
3. The precipitation sequence of the steel with relatively high $\mathrm{Ni} / \mathrm{Cu}$ and $\mathrm{Al} / \mathrm{Cu}$ ratios can be expressed as "supersaturated solid solution $\rightarrow \mathrm{NiAl} \rightarrow \mathrm{NiAl}+\mathrm{Cu}$ ", which is significantly different from the one previously reported in the $\mathrm{Cu}$-strengthened steels with relatively low $\mathrm{Ni} / \mathrm{Cu}$ and $\mathrm{Al} / \mathrm{Cu}$ ratios, involving the process of "supersaturated solid solution $\rightarrow \mathrm{Cu}$ $\rightarrow \mathrm{Cu}+\mathrm{NiAl}$ ". The modulation of the precipitation sequence is attributed not only to the relative high $\mathrm{Ni} / \mathrm{Cu}$ and $\mathrm{Al} / \mathrm{Cu}$ ratios but also the synergistic combination of $\mathrm{Ni}, \mathrm{Al}, \mathrm{Cu}$ and $\mathrm{Mn}$ additions, which leads to the formation of an extremely high number density of NiAl nanoparticles as the dominant strengthening phase.

4. By optimizing alloying additions of $\mathrm{Ni}, \mathrm{Al}, \mathrm{Cu}$ and $\mathrm{Mn}$, controlling the precipitation mechanism, and engineering the precipitation nanostructural features, the ultra-high strength ductile steel has been developed with a reduced Ni content as compared with maraging steels, showing a great potential for structural applications.

\section{Acknowledgments}

This research was supported by the internal funding from City University of Hong Kong (account No. 9380060). Atom probe tomography (M.K.M.) was conducted at the Center for Nanophase Materials Sciences at Oak Ridge National Laboratory, which is a DOE Office of Science User Facility located at Oak Ridge, Tennessee, USA. 


\section{References}

[1] A.S. Argon, Strengthening Mechanisms in Crystal Plasticity, Oxford University Press, Oxford, 2008.

[2] G. Trotter, G. Rayner, I. Baker, P.R. Munroe, Accelerated precipitation in the AFA stainless steel Fe-20Cr-30Ni-2Nb-5Al via cold working, Intermetallics 53 (2014) 120.

[3] S. Huang, Y. Gao, K. An, L. Zheng, W. Wu, Z. Teng, P.K. Liaw, Deformation mechanisms in a precipitation-strengthened ferritic superalloy revealed by in situ neutron diffraction studies at elevated temperatures, Acta Mater. 83 (2015) 137.

[4] T. Hayashi, P.M. Sarosi, J.H. Schneibel, M.J. Mills, Creep response and deformation processes in nanocluster-strengthened ferritic steels, Acta Mater. 56 (2008) 1407.

[5] H.W. Yen, P.Y. Chen, C.Y. Huang, J.R. Yang, Interphase precipitation of nanometer-sized carbides in a titanium-molybdenum-bearing low-carbon steel, Acta Mater. 59 (2011) 6264.

[6] M.J. Alinger, G.R. Odette, D.T. Hoelzer, On the role of alloy composition and processing parameters in nanocluster formation and dispersion strengthening in nanostuctured ferritic alloys, Acta Mater. 57 (2009) 392.

[7] A. Hirata, T. Fujita, C.T. Liu, M.W. Chen, Characterization of oxide nanoprecipitates in an oxide dispersion strengthened 14YWT steel using aberration-corrected STEM, Acta Mater. 60 (2012) 5696.

[8] E.J. Czyryca, Advances in high strength steel technology for naval hull construction, Key Eng. Mater. 84 (1993) 491.

[9] M.E. Fine, S. Vaynman, D. Isheim, Y.W. Chung, S.P. Bhat, C.H. Hahin, A new paradigm for designing high-fracture-energy steels, Metall. Mater. Trans. A 41 (2010) 3318. 
[10] M.D. Mulholland, D.N. Seidman, Nanoscale co-precipitation and mechanical properties of a high-strength low-carbon steel, Acta Mater. 59 (2011) 1881.

[11] R. Taillard, A. Pineau, Room temperature tensile properties of Fe-19wt.\% Cr alloys precipitation hardened by the intermetallic compound NiAl, Mater. Sci. Eng. 56 (1982) 219.

[12] H.A. Calderon, M.E. Fine, J.R. Weertman, Coarsening and morphology of $\beta$ ' particles in Fe-Ni-Al-Mo ferritic alloys, Metall. Trans. A 19 (1988) 1135.

[13] M.K. Miller, M.G. Hetherington, Atom probe analysis of $\beta^{\prime}$ precipitation in a model ironbased Fe-Ni-Al-Mo superalloys, J. de Phys. 50-C8 (1989) 425.

[14] Z.K. Teng, M.K. Miller, G. Ghosh, C.T. Liu, S. Huang, K.F. Russsell, M.E. Fine, P.K. Liaw, Characterization of nanoscale NiAl-type precipitates in a ferritic steel by electron microscopy and atom probe tomography, Scr. Mater. 63 (2010) 61.

[15] Z.W. Zhang, C.T. Liu, M.K. Miller, X.L. Wang, Y.R. Wen, T. Fujita, A. Hirata, M.W. Chen, G. Chen, B.A. Chin, A nanoscale co-precipitation approach for property enhancement of Fe-base alloys, Sci. Rep. 3 (2013) 1327.

[16] Y.R. Wen, A. Hirata, Z.W. Zhang, T. Fujita, C.T. Liu, J.H. Jiang, M.W. Chen, Microstructure characterization of $\mathrm{Cu}$-rich nanoprecipitates in a Fe-2.5 $\mathrm{Cu}-1.5 \mathrm{Mn}-4.0 \mathrm{Ni}-$ 1.0 Al multicomponent ferritic alloy, Acta Mater. 61 (2013) 2133.

[17] M. Kapoor, D. Isheim, G. Ghosh, S. Vaynman, M.E. Fine, Y.W. Chung, Aging characteristics and mechanical properties of 1600MPa body-centered cubic $\mathrm{Cu}$ and $\mathrm{B} 2-\mathrm{NiAl}$ precipitation-strengthened ferritic steel, Acta Mater. 73 (2014) 56.

[18] X. Wang, G. Sha, Q. Shen, W. Liu, Age-hardening effect and formation of nanoscale composite precipitates in a NiAlMnCu-containing steel, Mater. Sci. Eng. A 627 (2015) 340. 
[19] S.K. Lahiri, D. Chandra, L.H. Schwartz, M.E. Fine, Modulus and Mossbauer studies of precipitation in Fe-1.67 at pct Cu, Trans. Metall. Soc. AIME 245 (1969) 1865.

[20] P.J. Othen, M.L. Jenkins, G.D.W. Smith, High-resolution electron microscopy studies of the structure of Cu precipitates in $\alpha$-Fe, Philos. Mag. A 70 (1994) 1.

[21] R. Monzen, M.L. Jenkins, A.P. Sutton, Structural changes of 9R copper precipitates in an aged Fe-Cu alloy, Phil. Mag. A 80 (2000) 711.

[22] M.K. Miller, B.D. Wirth, G.R. Odette, Precipitation in neutron-irradiated $\mathrm{Fe}-\mathrm{Cu}$ and $\mathrm{Fe}-\mathrm{Cu}-$ Mn model alloys: a comparison of APT and SANS data, Mater. Sci. Eng. A 353 (2003) 133.

[23] M.K. Miller, K.F. Russell, Embrittlement of RPV steels: An atom probe tomography perspective, J. Nucl. Mater. 37 (2007) 145.

[24] D. Isheim, M.S. Gagliano, M.E. Fine, D.N. Seidman, Interfacial segregation at Cu-rich precipitates in a high-strength low-carbon steel studied on a sub-nanometer scale, Acta Mater. 54 (2006) 841.

[25] R.P. Kolli, D.N. Seidman, The temporal evolution of the decomposition of a concentrated multicomponent Fe-Cu-based steel, Acta Mater. 56 (2008) 2073.

[26] Z.B. Jiao, J.H. Luan, Z.W. Zhang, M.K. Miller, W.B. Ma, C.T. Liu, Synergistic effects of $\mathrm{Cu}$ and $\mathrm{Ni}$ on nanoscale precipitation and mechanical properties of high-strength steels, Acta Mater. 61 (2013) 5996.

[27] K.S. Kumar, S.K. Mannan, R.K. Viswanadham, Fracture toughness of NiAl and NiAl-based composites, Acta Metall. Mater. 40 (1992) 1201.

[28] C.T. Liu, Recent advances in ordered intermetallics, Mater. Chem. Phys. 42 (1995) 77.

[29] H. Bei, S. Shim, G.M. Pharr, E.P. George, Effects of pre-strain on the compressive stressstrain response of Mo-alloy single-crystal micropillars, Acta Mater. 56 (2008) 4762. 
[30] M.K. Miller, Atom Probe Tomography: Analysis at the Atomic Level, Springer, New York, 2000.

[31] D.N. Seidman, Three-dimensional atom-probe tomography: advances and applications, Annu. Rev. Mater. Res. 37 (2007) 127.

[32] T.F. Kelly, D.J. Larson, K. Thompson, R.L. Alvis, J.H. Bunton, J.D. Olson, B.P. Gorman, Atom probe tomography of electronic materials, Annu. Rev. Mater. Res. 37 (2007) 681.

[33] G.B. Olson, Computational design of hierarchically structured materials, Science, 277 (1997) 1237.

[34] J.C. Zhao, Combinatorial approaches as effective tools in the study of phase diagrams and composition-structure-property relationships, Prog. Mater. Sci. 51 (2006) 557.

[35] N. Bailey, Welding Steels without Hydrogen Cracking, Woodhead Publishing, Cambridge, 1993.

[36] R.E. Smallman, A.H.W. Ngan, Modern Physical Metallurgy, Butterworth-Heinemann, London, 2013.

[37] C.L. Briant, S.K. Banerji, Intergranular failure in steel: the role of grain-boundary composition, Int. Metal Rev. 23 (1978) 164.

[38] C.T. Liu, J.O. Stiegler, Ductile ordered intermetallic alloys, Science 226 (1984) 636.

[39] I. Baker, P. R. Munroe, Improving intermetallic ductility and toughness, JOM, 40 (1988) 28.

[40] Z.B. Jiao, J.H. Luan, Z.W. Zhang, M.K. Miller, C.T. Liu, High-strength steels hardened mainly by nanoscale NiAl precipitates, Scr. Mater. 87 (2014) 45 .

[41] I. Le May, L.M. Schetky, Copper in Iron and Steel, Wiley, New York, 1982.

[42] D. Raabe, D. Ponge, O. Dmitrieva, B. Sander, Nanoprecipitate-hardened 1.5 GPa steels with unexpected high ductility, Scr. Mater. 60 (2009) 1141. 
[43] L. Schäfer, Influence of delta ferrite and dendritic carbides on the impact and tensile properties of a martensitic chromium steel, J. Nucl. Mater. 263 (1998) 1336.

[44] Z.B. Jiao, J.H. Luan, M.K. Miller, C. Y. Yu, C.T. Liu, Effects of Mn partitioning on nanoscale precipitation and mechanical properties of ferritic steels strengthened by $\mathrm{NiAl}$ nanoparticles, Acta Mater. 84 (2015) 283.

[45] P.J. Pareige, K.F. Russell, M.K. Miller, APFIM studies of the phase transformations in thermally aged ferritic FeCuNi alloys: Comparison with aging under neutron irradiation, Appl. Surf. Sci. 94 (1996) 362.

[46] G. Bozzolo, H.O. Mosca, A.W. Wilson, R.D. Noebe, J.E. Garces, Atomistic modeling of quaternary alloys: Ti and Cu in NiAl, Metall. Mater. Trans. B 33 (2002) 265.

[47] W.F. Gale, T.C. Totemeier, Smithells Metals Reference Book, Butterworth-Heinemann, London, 2003.

[48] A. Takeuchi, A. Inoue, Calculations of mixing enthalpy and mismatch entropy for ternary amorphous alloys, Mater. Trans. JIM 41 (2000) 1372.

[49] M.J. Mills, D.B. Miracle, The structure of $a<100>$ and $a<110>$ dislocation cores in NiAl, Acta Metall. 41 (1993) 85. 


\section{Figure legends}

Fig. 1 Calculated phase fractions as a function of alloying addition and temperature: (a) $\mathrm{Cu}$ phase at 550 and $900{ }^{\circ} \mathrm{C}$, (b) retained austenite at $550{ }^{\circ} \mathrm{C}$, (c) $\delta$-ferrite at $900{ }^{\circ} \mathrm{C}$, and (d) intersections of the composition range fulfilling the design requirements.

Fig. 2 Hardness as a function of aging time at $400-550{ }^{\circ} \mathrm{C}$ for the studied steel.

Fig. 3 Room-temperature tensile stress-strain curve of the steel aged for $2 \mathrm{~h}$ at $550{ }^{\circ} \mathrm{C}$ and the insets showing the fracture surfaces.

Fig. 4 (a) TEM bright-field image of nanoscale $\mathrm{Fe}_{3}(\mathrm{Mo}, \mathrm{W})_{3} \mathrm{C}$ - and $\mathrm{NbC}$-type carbides. The insets show a HRTEM image of a representative $\mathrm{Fe}_{3}(\mathrm{Mo}, \mathrm{W})_{3} \mathrm{C}$-type carbide and its FFT pattern. (b) EDS spectra for the $\mathrm{Fe}_{3}(\mathrm{Mo}, \mathrm{W})_{3} \mathrm{C}$ - and NbC-type carbides.

Fig. 5 Nanostructures of the NiAl and Cu particles in the aged specimens: (a) $0.5 \mathrm{~h}$, (b) $2 \mathrm{~h}$, (c) 8 $\mathrm{h}$, and (d) $128 \mathrm{~h}$.

Fig. 6 (a) Particle radius and (b) number density of the $\mathrm{NiAl}$ and $\mathrm{Cu}$ nanoparticles as a function of aging time.

Fig. 7 Fractions of the isolated $\mathrm{NiAl}$ particles and $\mathrm{NiAl} / \mathrm{Cu}$ co-precipitates as a function of aging time.

Fig. 8 1-nm-thick atom maps showing the $\mathrm{Al}$ (cyan), $\mathrm{Ni}$ (red) and $\mathrm{Cu}$ (green) atoms through the centers of isolated $\mathrm{NiAl}$ particles and $\mathrm{NiAl} / \mathrm{Cu}$ co-precipitates in the aged specimens: (a) $0.5 \mathrm{~h}$, (b) $2 \mathrm{~h}$, and (c) $8 \mathrm{~h}$. 
Fig. 9 APT compositions of the (a) $\mathrm{NiAl}$ and (b) $\mathrm{Cu}$ nanoparticles as a function of aging time.

Fig. 10 Schematics showing the precipitation mechanism of the $\mathrm{NiAl}$ and $\mathrm{Cu}$ nanoparticles in the steel with relatively high $\mathrm{Ni} / \mathrm{Cu}$ and $\mathrm{Al} / \mathrm{Cu}$ ratios. 
Fig. 1
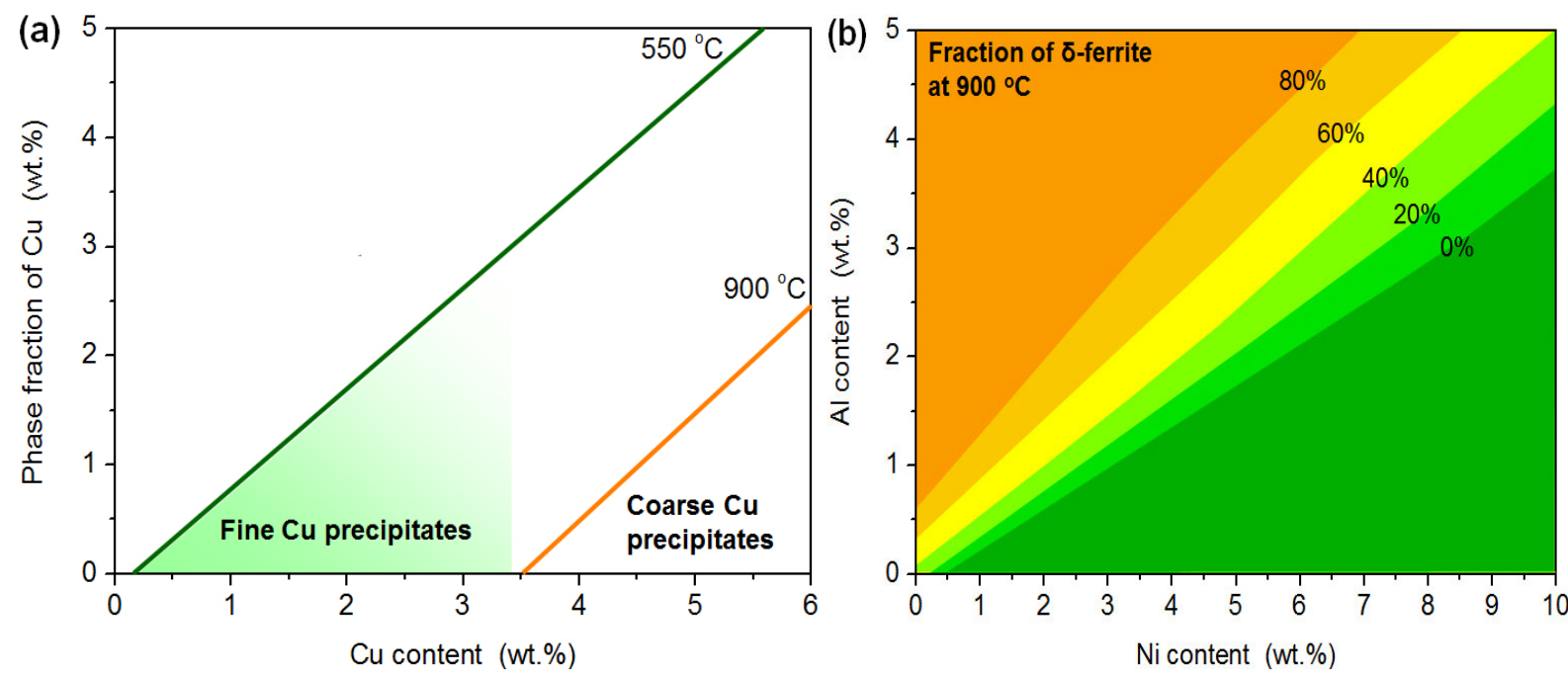

Fig. 1 (cont'd)
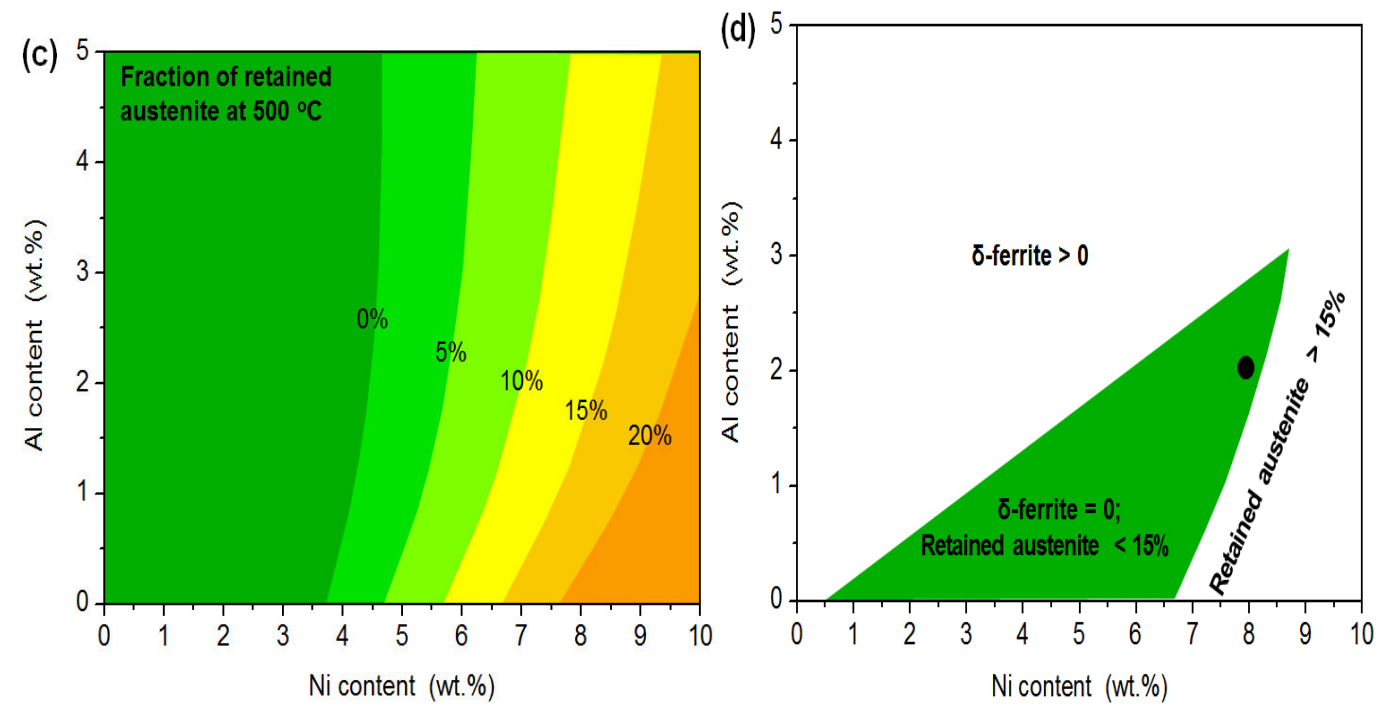
Fig. 2

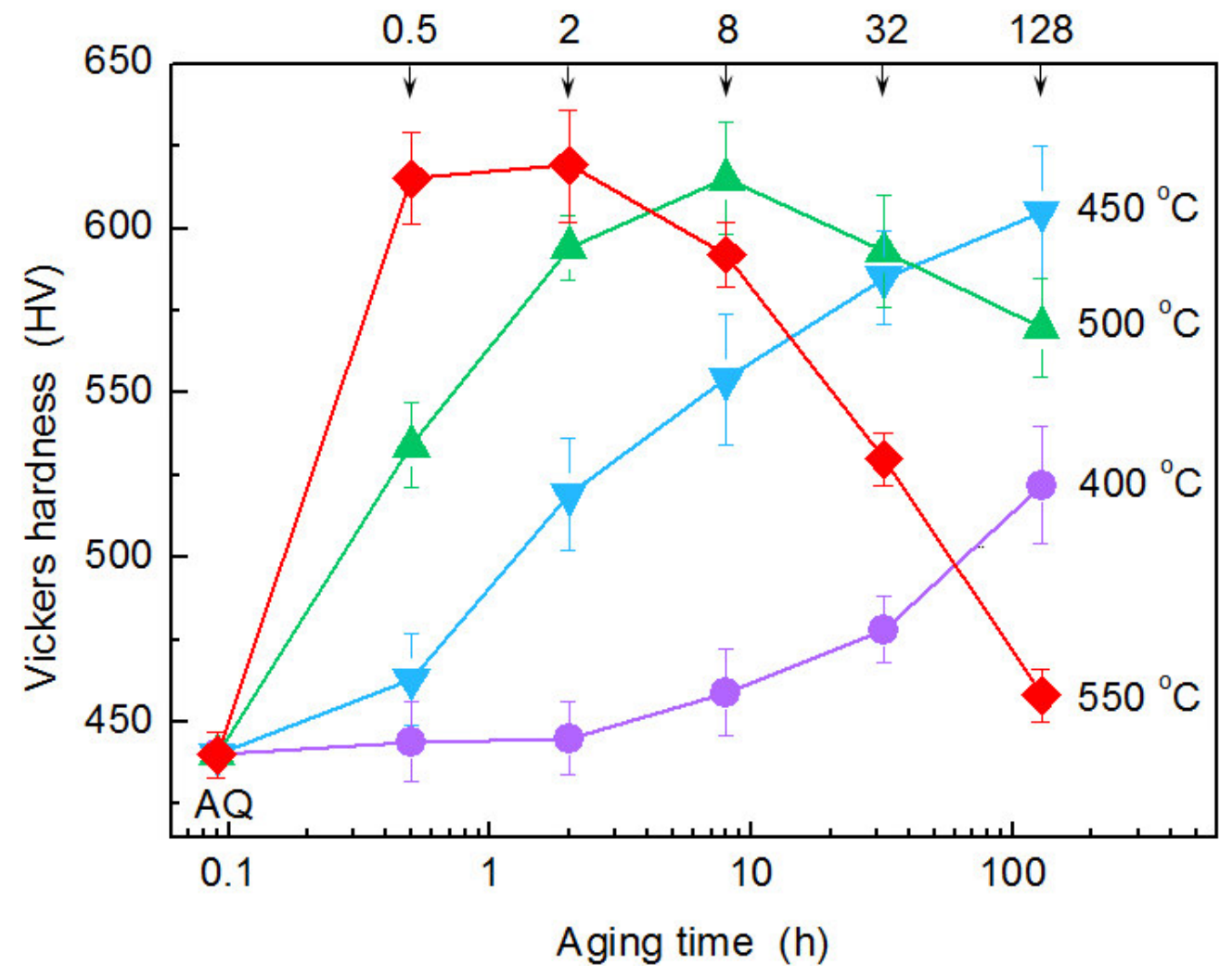


Fig. 3

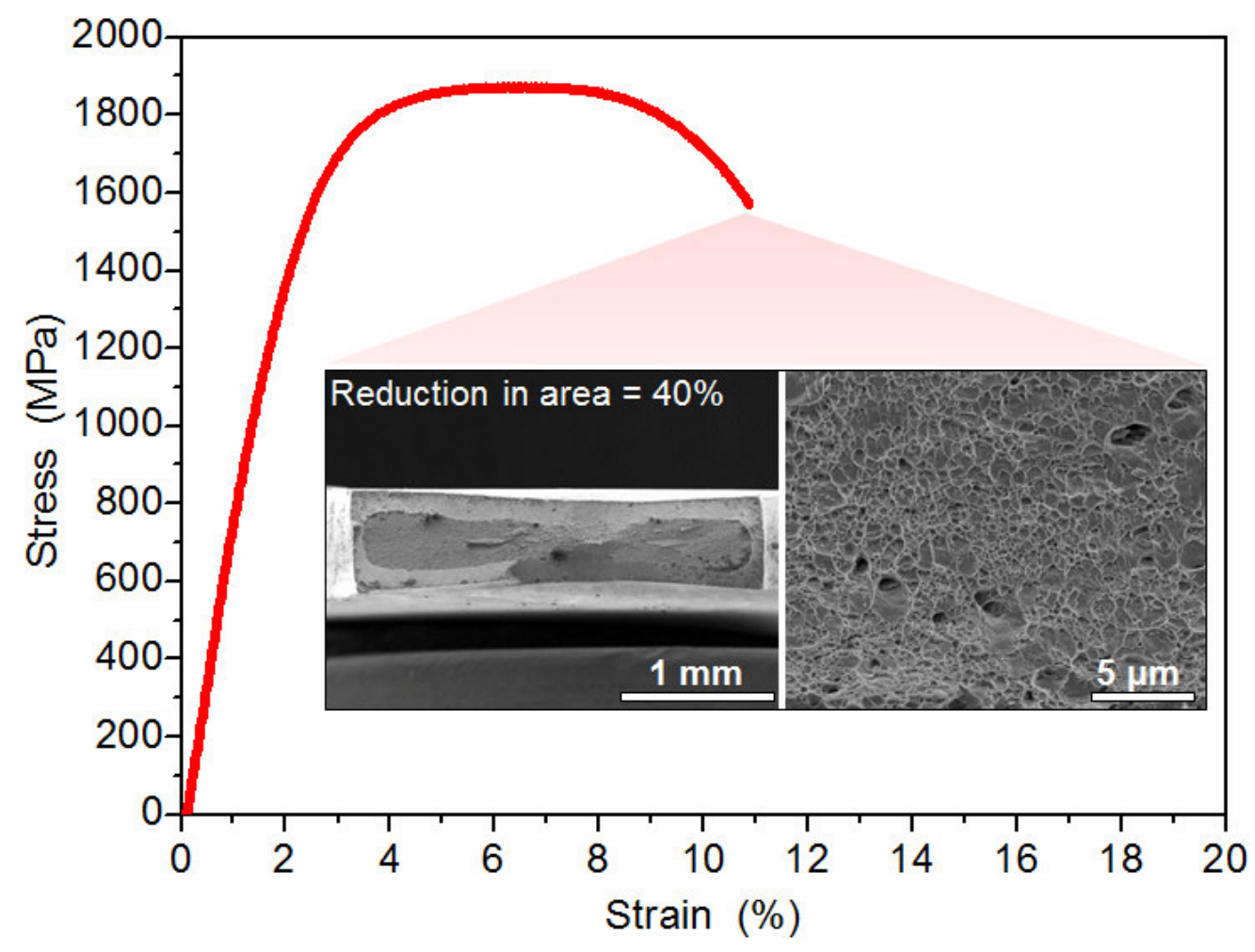


Fig. 4
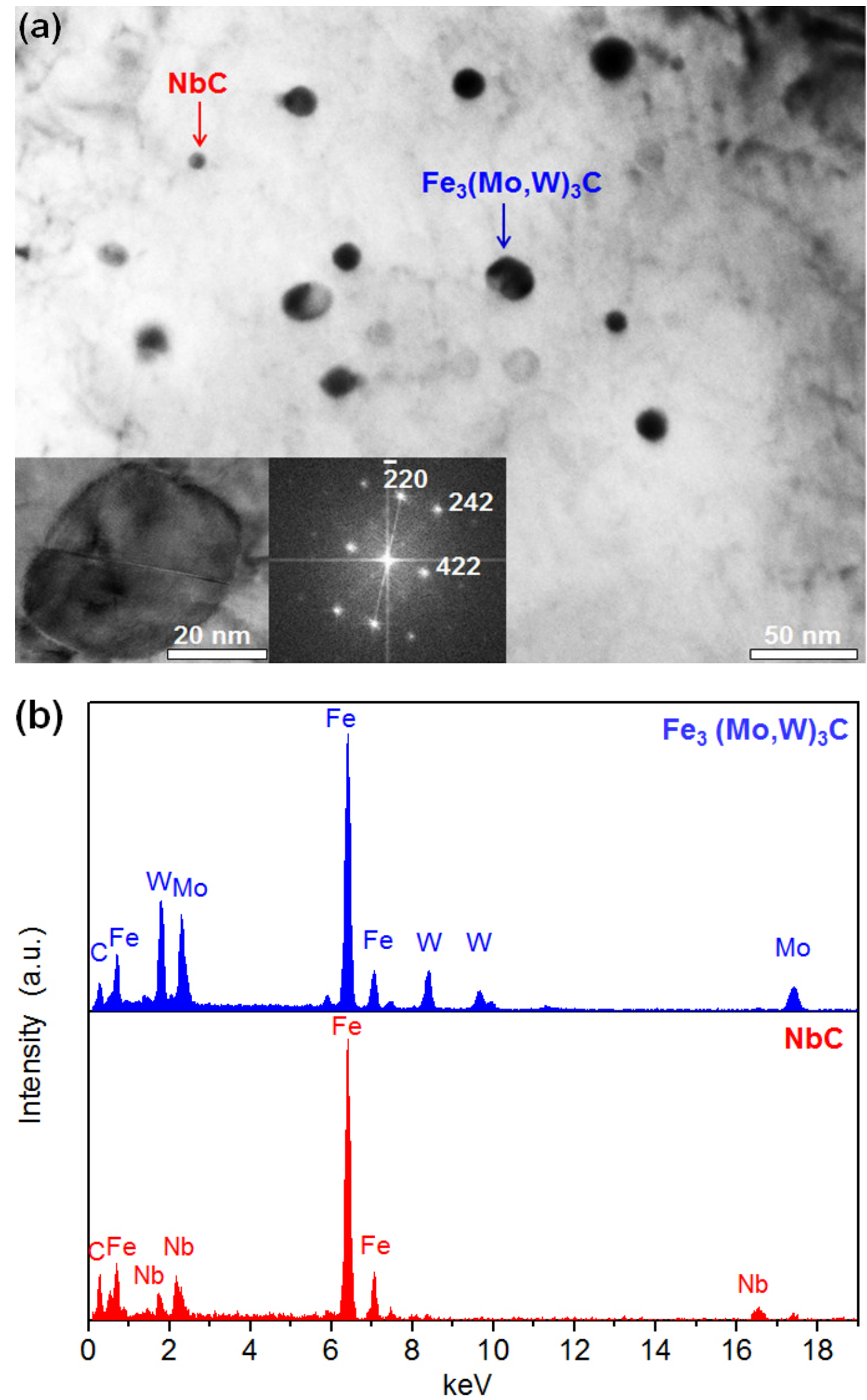
Fig. 5
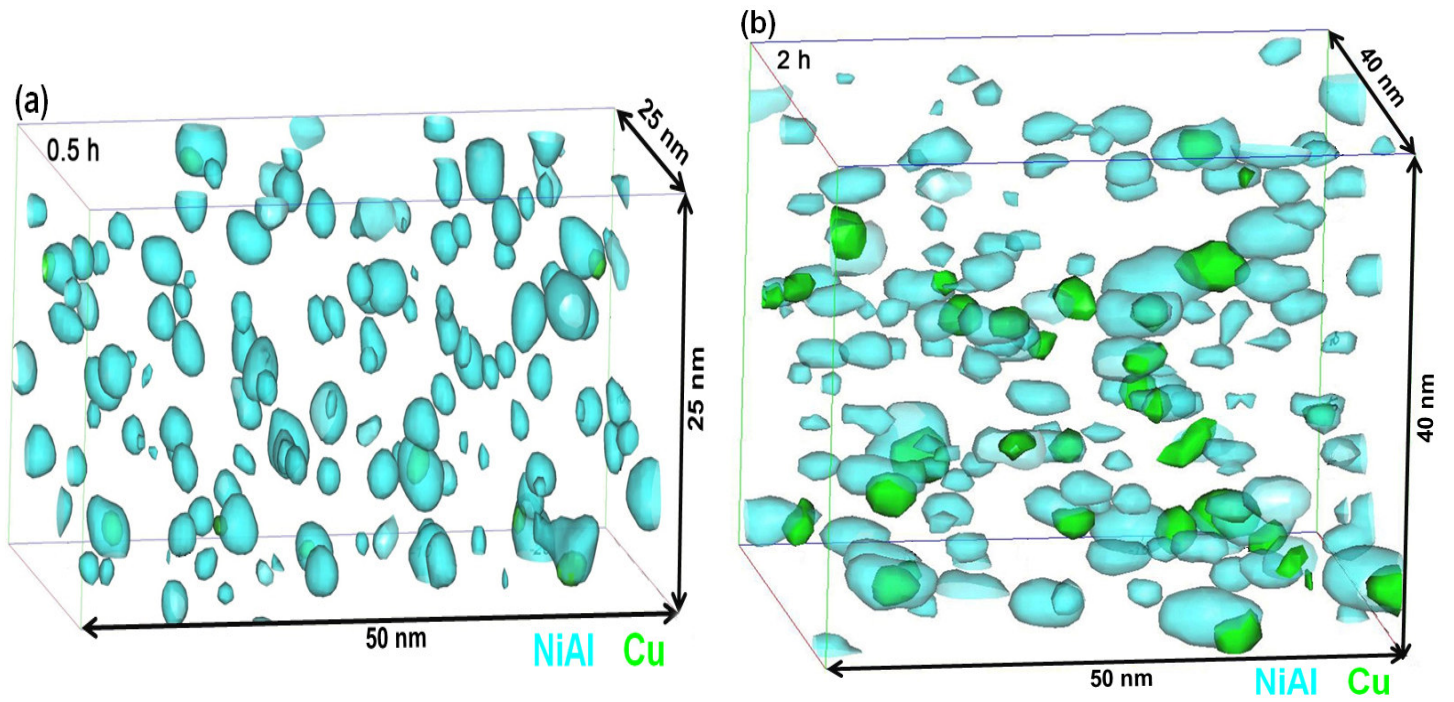

Fig. 5 (cont'd)
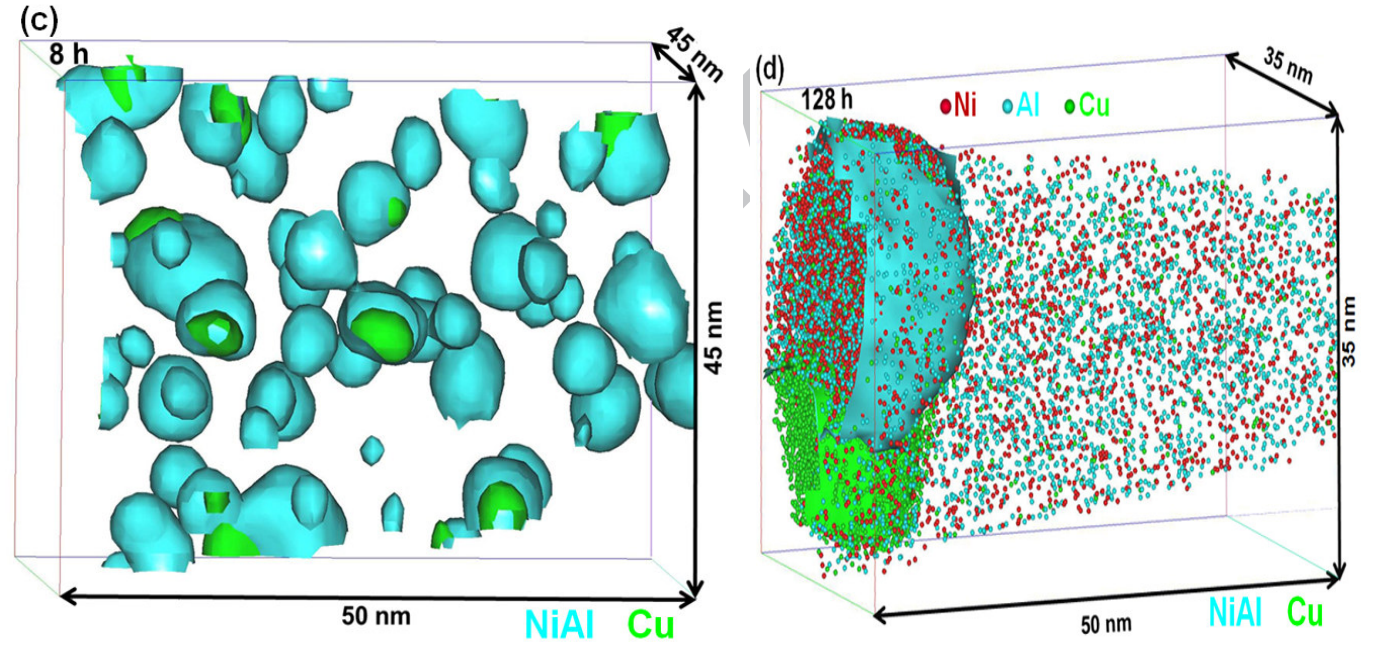
Fig. 6
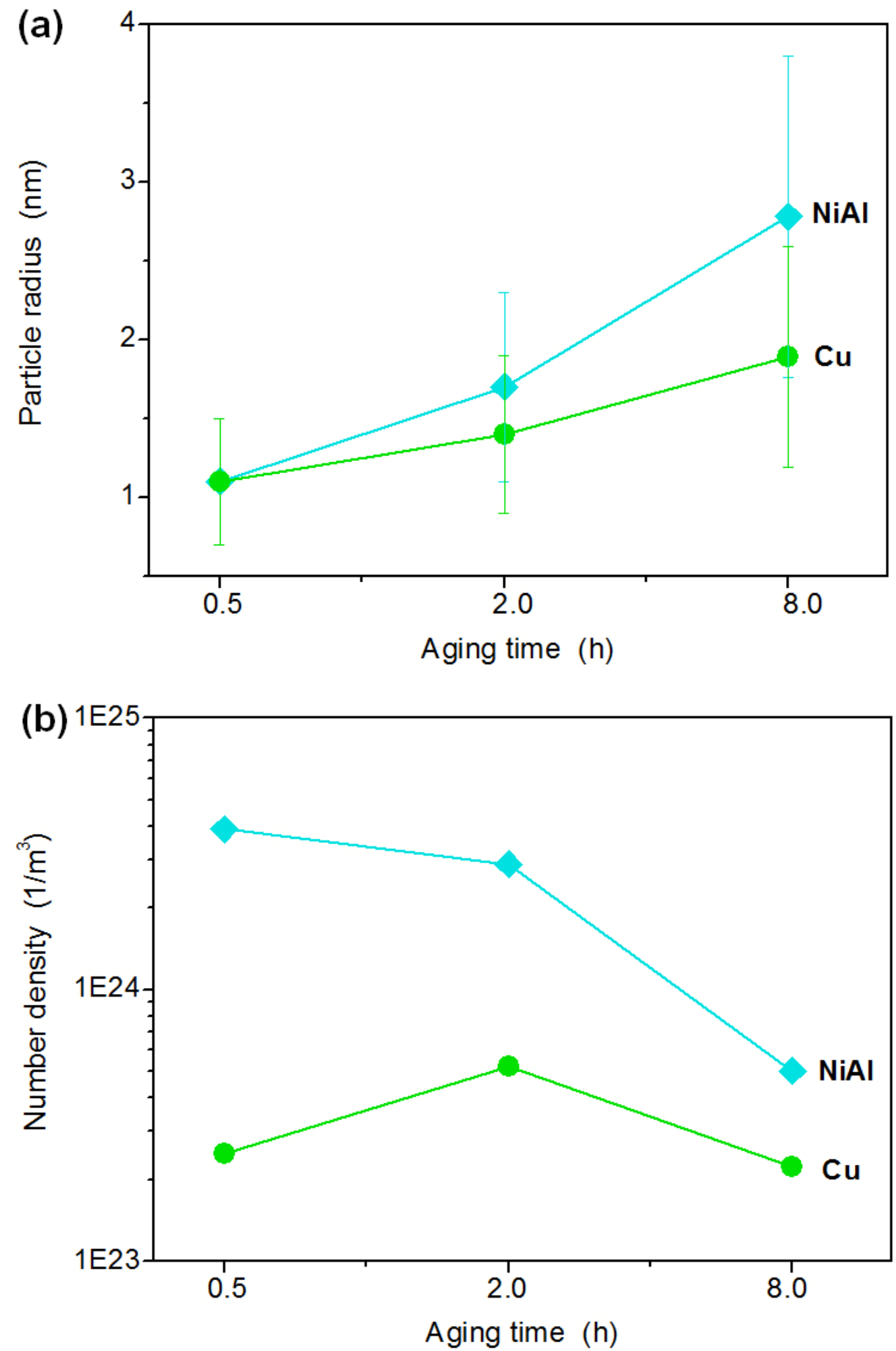
Fig. 7

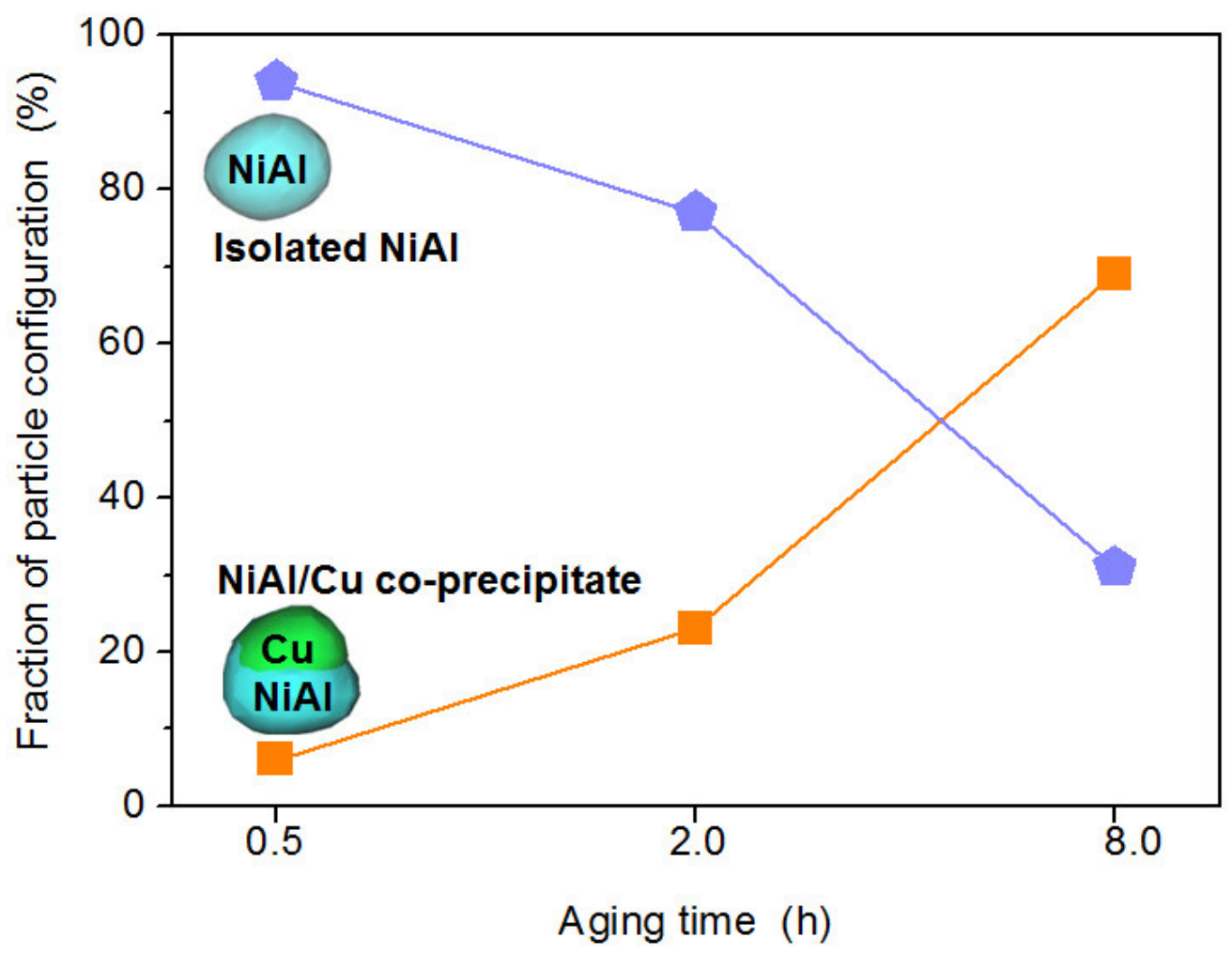


Fig. 8

(a) Isolated NiAl

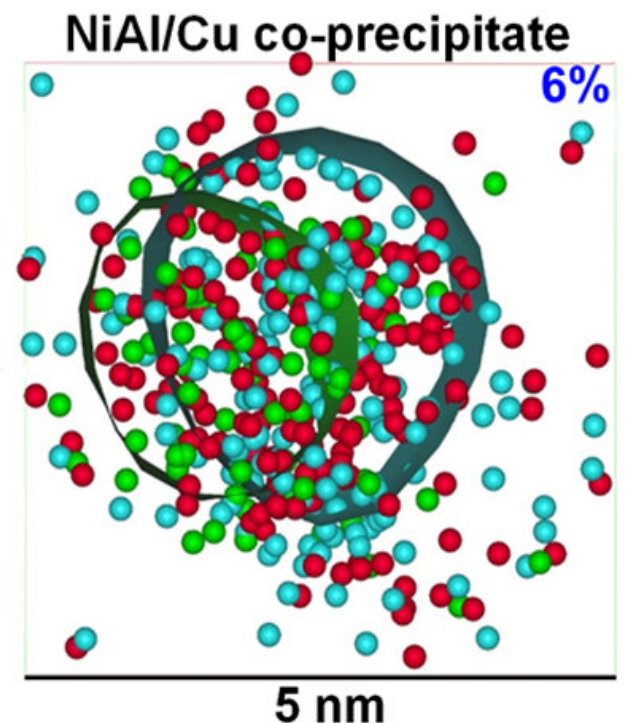

(b)

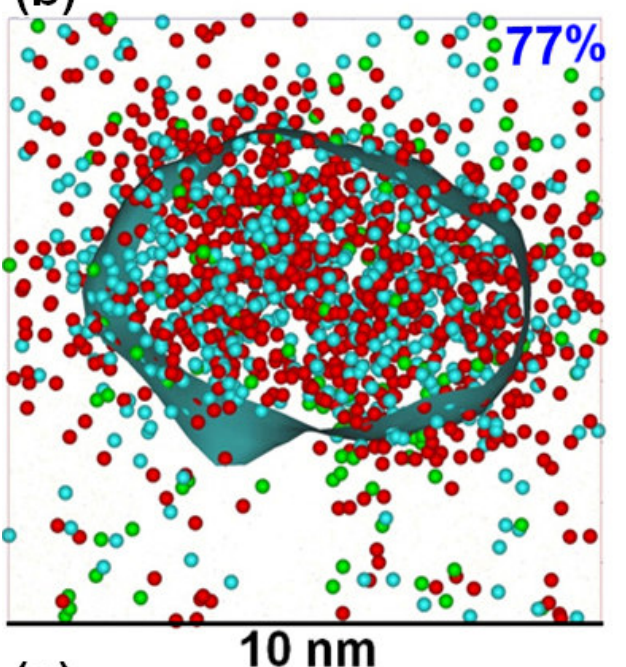

(c)
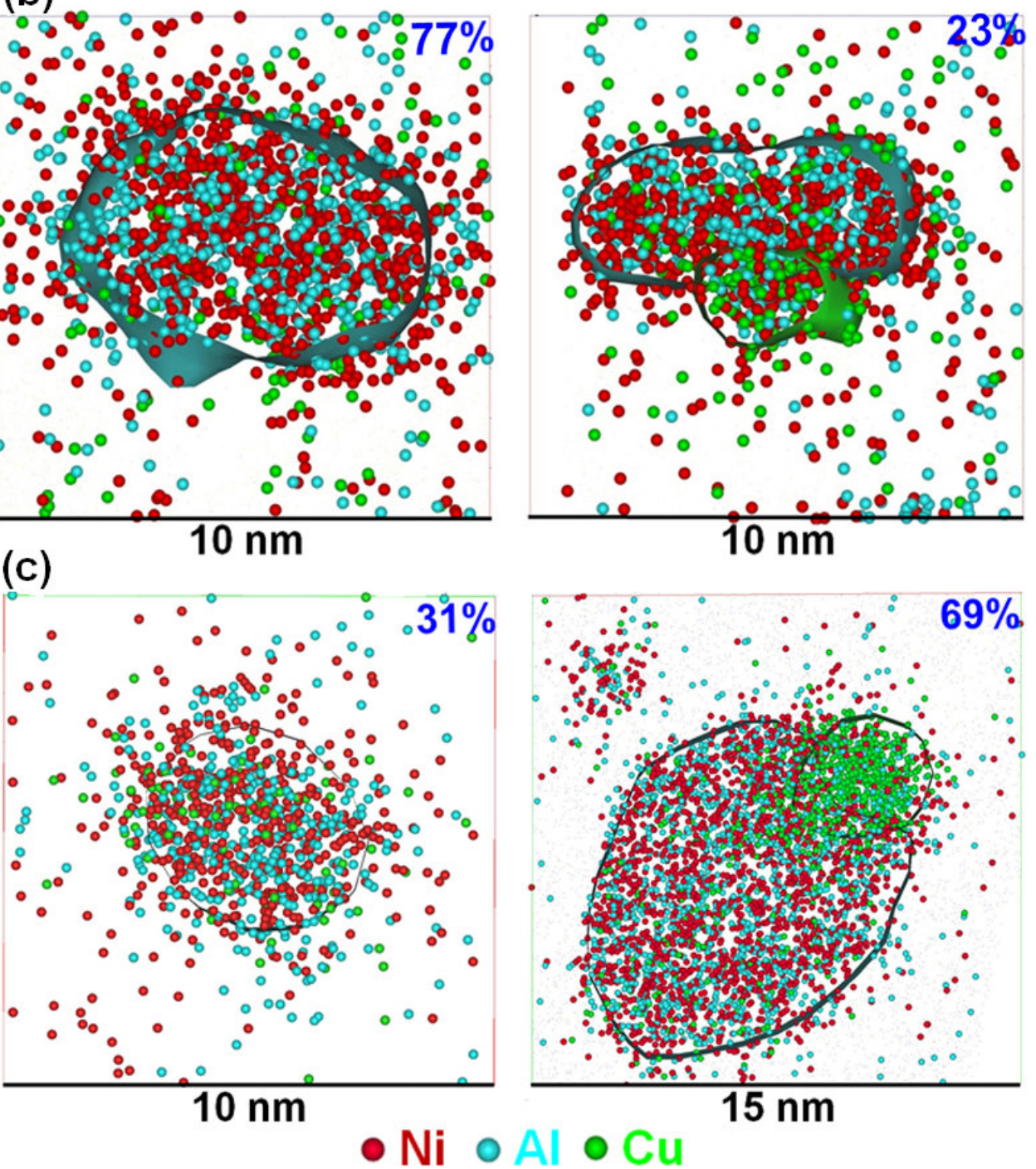
Fig. 9
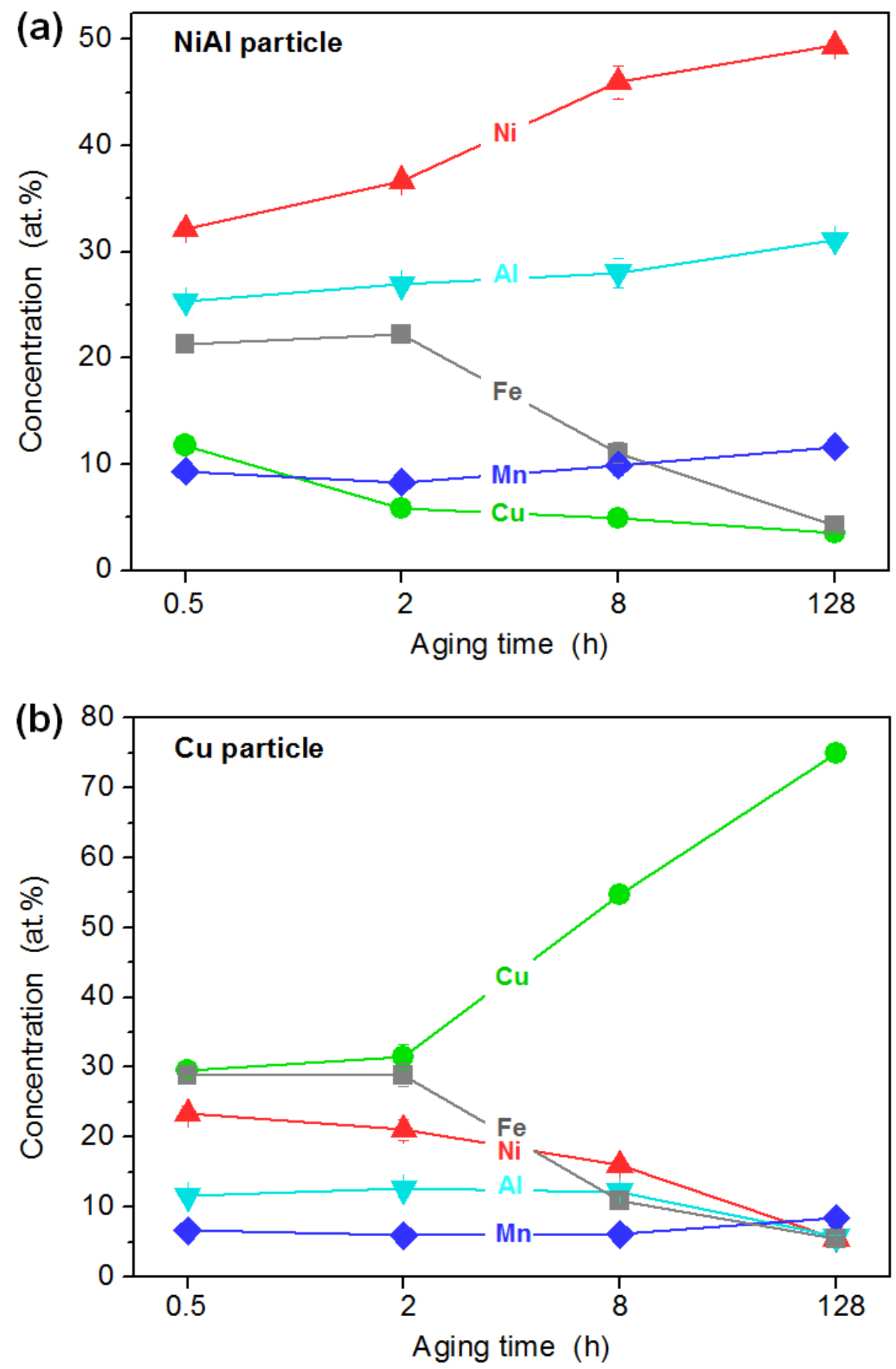
Fig. 10

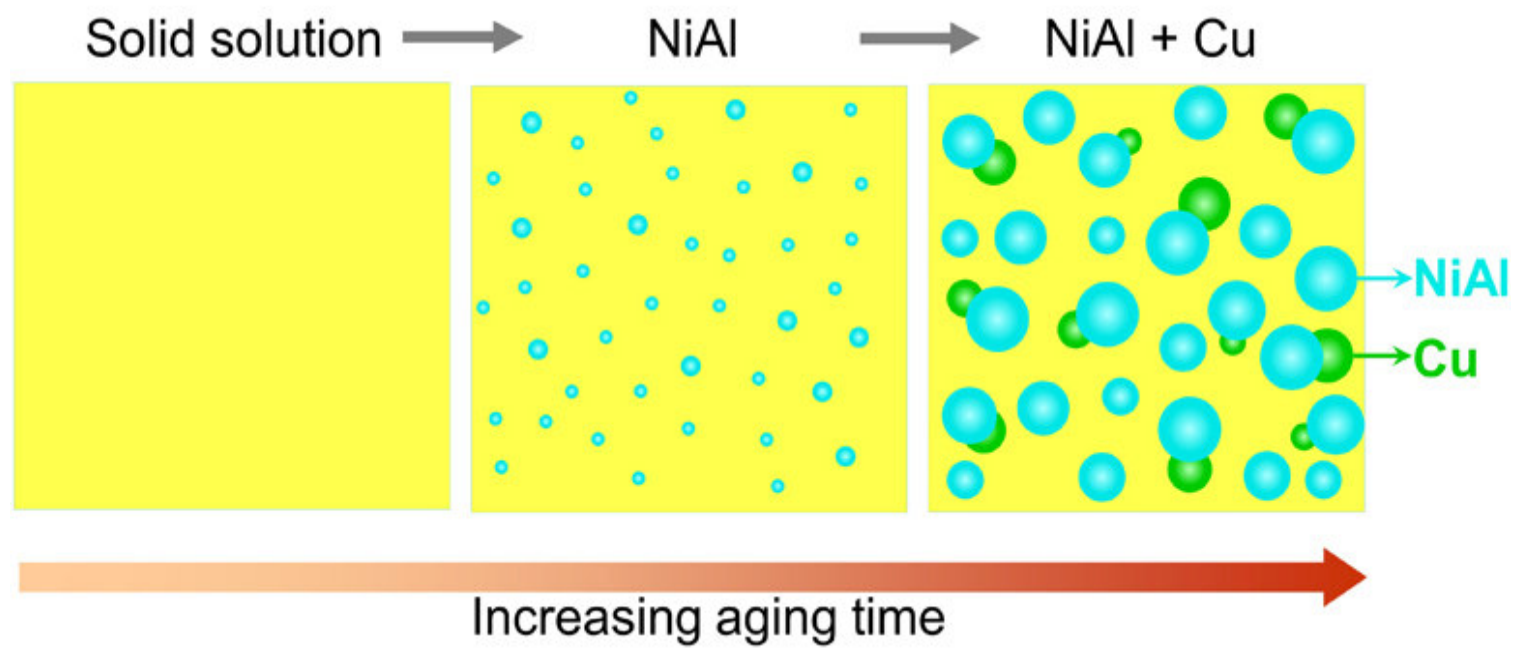


Table 1. APT compositions of the nanoscale carbides in the $2 \mathrm{~h}$ condition (at.\%).

\begin{tabular}{|c|c|c|c|c|c|c|c|c|}
\hline carbide & $\mathrm{C}$ & Mo & W & $\mathrm{Nb}$ & $\mathrm{Fe}$ & $\mathrm{Ni}$ & $\mathrm{Al}$ & $\mathrm{Mn}$ \\
\hline $\mathrm{Fe}_{3}(\mathrm{Mo}, \mathrm{W})_{3} \mathrm{C}$ & $\begin{array}{c}16.51 \\
\pm 0.05\end{array}$ & $\begin{array}{l}29.42 \\
\pm 0.08\end{array}$ & $\begin{array}{r}12.68 \\
\pm 0.07\end{array}$ & $\begin{array}{c}0.95 \\
\pm 0.03\end{array}$ & $\begin{array}{l}37.23 \\
\pm 0.15\end{array}$ & $\begin{array}{c}0.83 \\
\pm 0.02\end{array}$ & $\begin{array}{c}1.16 \\
\pm 0.02\end{array}$ & $\begin{array}{c}1.22 \\
\pm 0.02\end{array}$ \\
\hline $\mathrm{NbC}$ & $\begin{array}{l}41.71 \\
\pm 0.57\end{array}$ & $\begin{array}{l}11.02 \\
\pm 0.37\end{array}$ & $\begin{array}{r}12.56 \\
\pm 0.31\end{array}$ & $\begin{array}{c}22.81 \\
\pm 0.47\end{array}$ & $\begin{array}{c}9.81 \\
\pm 0.35\end{array}$ & $\begin{array}{c}0.71 \\
\pm 0.15\end{array}$ & $\begin{array}{c}0.62 \\
\pm 0.10\end{array}$ & $\begin{array}{c}0.76 \\
\pm 0.11\end{array}$ \\
\hline
\end{tabular}


Table 2. Compositions and $\mathrm{Ni} / \mathrm{Cu}$ and $\mathrm{Al} / \mathrm{Cu}$ ratios in $\mathrm{Cu}-$ and $\mathrm{NiAl}$-strengthened steels (wt.\%).

\begin{tabular}{ccccccc}
\hline $\mathrm{Cu}$ & $\mathrm{Ni}$ & $\mathrm{Al}$ & $\mathrm{Mn}$ & $\mathrm{Ni} / \mathrm{Cu}$ & $\mathrm{Al} / \mathrm{Cu}$ & Ref. \\
\hline 1.37 & 0.82 & 0.03 & 0.49 & 0.60 & 0.02 & {$[24]$} \\
2.00 & 0.75 & 0.30 & 0.75 & 0.38 & 0.15 & {$[26]$} \\
2.09 & 2.83 & 0.68 & 0.50 & 1.35 & 0.33 & {$[25]$} \\
2.50 & 2.50 & 1.00 & 1.50 & 1.00 & 0.40 & {$[15]$} \\
2.50 & 4.00 & 1.00 & 1.50 & 1.60 & 0.40 & {$[16]$} \\
3.00 & 4.00 & 1.50 & 3.00 & 1.33 & 0.50 & {$[17]$} \\
1.50 & 5.00 & 2.00 & 3.00 & 3.33 & 1.33 & This study \\
\hline
\end{tabular}




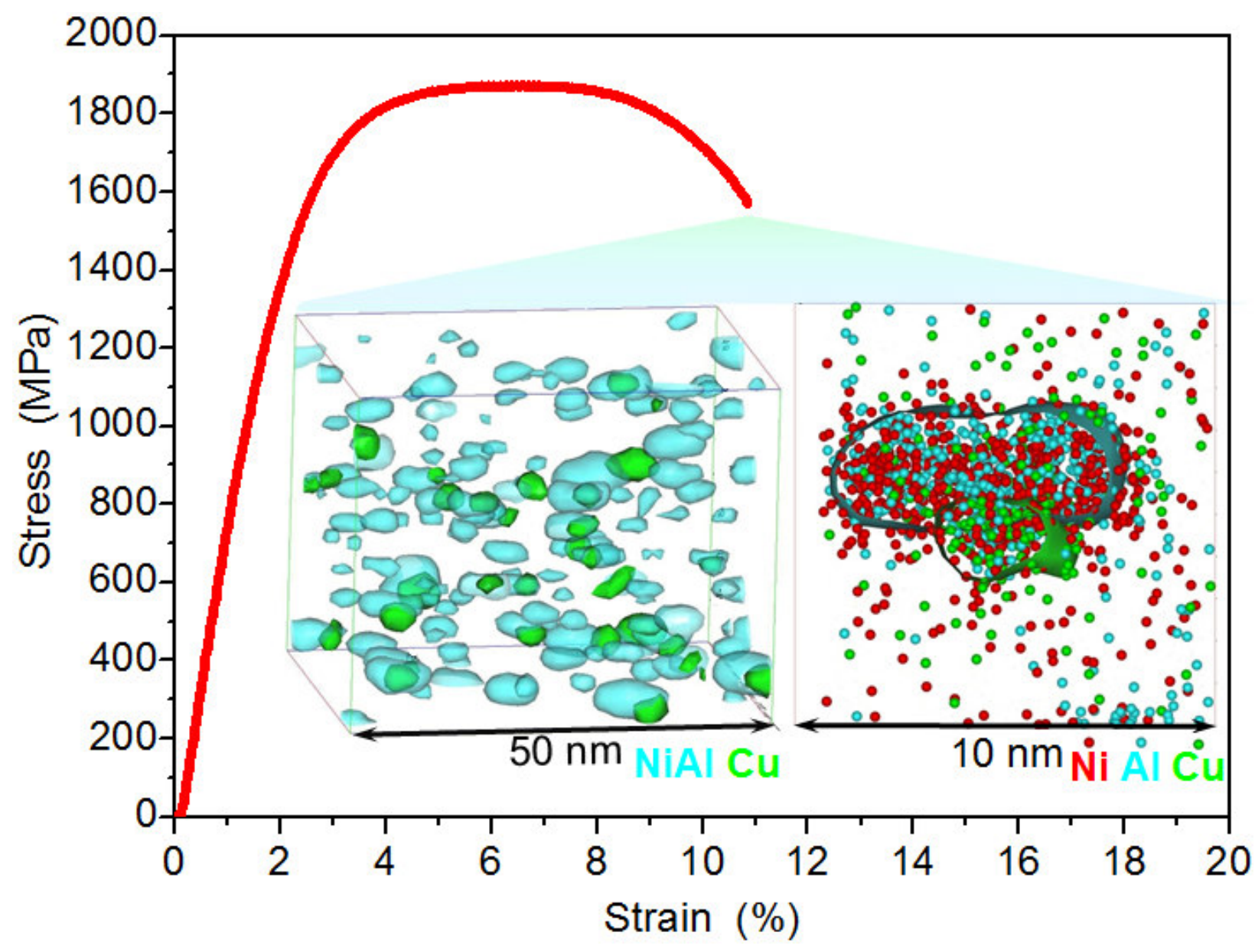

